\title{
Geo-environmental monitoring and 3D finite elements stability analysis for site investigation of underground monuments. Horemheb tomb (KV57), Luxor, Egypt
}

Sayed Hemeda ${ }^{1,2^{*}}$ (1)

\begin{abstract}
The Valley of the Kings (KV) is a UNESCO world heritage site with more than thirty opened tombs. Since the first tombs were constructed, at least 24 historical flash flood events has been identified, each of which has been contributed to the destruction and deterioration of the tombs. Recently, most of these tombs have been damaged and inundated after 1994 flood. In order to understand the Geo-environmental impact mainly the past flash floods due to the intensive rainfall storm on the valley of kings and the long-term rock mass behavior under geostatic stresses in selected Horemheb tomb (KV57) and its impact on past failures and current stability, Remote sensing, GIS, LIDAR, 3D finite element stability analysis and rock mass quality assessments had been carried out using advanced methods and codes. Our work provides environmental satellite space views via landviewer Erath Observation System (EOS) Platform with passive and active sensors which include the Normalized Difference Vegetation Index (NDVI), SoilAdjusted Vegetation Index (SAVI), Atmospherically resistant vegetation index (ARVI), Green Chlorophyll Index (GCI), Normalized Burn Ratio (NBR), Normalized Difference Snow Index (NDSI), Light Detection And Ranging (LIDAR) images, Terrain (DEM) Digital Elevation Models, 3D geological maps. In other hand experimental and numerical geotechnical evaluations and modeling of the rock mass of these underground structures and their surroundings have been executed. We estimated the rock mass quality of the different members within the Thebes limestone and Esna shale formations using the mechanical testing and Rock Mass Rating (RMR), rock quality system (Q-system) and Geological Strength Index (GSI) systems. Our recent analyses show that the KV57 rock- cut tomb at Luxor has been cut into poor to very poor quality marl shale masses due to the impact of flash foods. Rock failures of ceilings and pillars were frequently facilitated by local, unfavorably oriented persistent discontinuities, such as tension cracks and faults. Other failures were related to the disintegration of the marl limestone and Esna shale Formations into individual nodules upon weathering. Our data suggest that, in ancient Egypt monumental tomb construction, low-strength rock masses rarely resulted in modifications of the planned tomb design in order to minimise the risk of rock falls and to prevent collapses. The current flood protection measures are not enough. For this two following measures are proposed 1-to rise the current wall by $50 \mathrm{~cm}$. 2-to fill the depression by reshaping bathymetry.
\end{abstract}

Keywords: Flash floods, Geo-environmental investigation, Remote sensing, Geotechnical modeling, Horemheb tomb (KV57), Valley of the kings, Underground monuments

\footnotetext{
*Correspondence: sayed.hemeda@cu.edu.eg

1 Conservation Department, Faculty of Archaeology, Cairo University, Giza, Egypt

${ }^{2}$ School of Basic and Applied Science- BAS, Egypt-Japan University of Science and Technology (E-JUST), Alexandria, Egypt Full list of author information is available at the end of the article
}

\section{Introduction}

According to the Global Assessment Report on Disaster Risk Reduction (GAR) [1], flash floods are the most widely distributed natural hazards in Egypt. They also 
cause huge damages in the surrounding countries. Natural disasters in Egypt include also the earthquakes, desert locust and storms. The Global Assessment Report on Disaster Risk Reduction (GAR) is the flagship report of the United Nations on worldwide efforts to reduce disaster risk. The GAR is published biennially by the UN Office for Disaster Risk Reduction (UNDRR), and is the product of the contributions of nations, public and private risk-related science and research, amongst others.

Previous years UNESCO reports indicated, among other things, the following factors and threats, which were considered to have a severe impact on cultural heritage properties in Ancient Thebes with its Necropolis:

Changes in traditional ways of life and knowledge system, Deliberate destruction of heritage, Flooding, Housing Impacts of tourism/visitor/recreation, Land conversion, Management activities, Management systems/management plan, and Water (rain/water table). other threats include Natural decay and structural problems [2].

- Flood hazards (valleys of kings and queens).

- High groundwater level.

- Lack of a comprehensive management plan.

- Major and ongoing infrastructure and development projects.

- Uncontrolled urban development.

- Residential and agricultural crawl or creep on the west bank of the Nile.

To the north of Aswan area, in the region between Luxor and Southern Beni Suef, along the Nile River, there is a low seismicity level, which coincides with the main trend of the Nile River. This active area has been considered as a separate seismogenic source. Several historical earthquakes are reported to occur along the Nile River in this area source that may be due to the high population density along the Nile River in the ancient times. These earthquakes are the 600 B.C., 27 B.C., 857, 967, 997, 1264, 1299, 1694, 1778, and 1850 events. Their intensities range from V to VIII. Focal mechanism solutions exhibit reverse faulting mechanism to the west of the Nile River, in the area between Luxor and Assiut. However, normal faulting mechanism with strike-slip component appears to the north of Assiut till Beni Suef city, [3]. An integrated interpretation of ERT, SSR, and GPR surveys should be performed at the site of KV57 to successfully investigate the groundwater aquifer and water table elevation and assist hazard mitigation; these techniques are well described in details in some recent references like [4-6].

Great efforts have been made to preserve the archaeological site of the Valley of the Kings (KV) since UNESCO declared it a World Heritage Area in 1979. Explorations have been made to restore monuments and temples and investigate damage, degradation, and risk structures by many international groups of scientists inside and around KV. Many researchers [7-20] summarized that Egyptian monuments mainly fail due to deterioration or cracking of building materials, weak soft soil (for example, clay), and displacement along natural fractures in hard rocks (for example, limestone, sandstone, strong clay), or falling rock from steep slopes drifts.

The Valley of the Kings was a burial place for Egypt's pharaohs during the reign of the new king from 1550 to $1070 \mathrm{BC}$. KV is a small valley cut by heavy rain and eroded during several periods of rivers in the Eocene into a thick layer of limestone located around a sliced layer of marly shale. The valley is located at an altitude of $70 \mathrm{~m}$ above the level of the Nile River ( $140 \mathrm{~m}$ above average sea level) and the height of the surrounding hills is $80 \mathrm{~m}$ above the valley floor, as shown in Fig. 1. During the late eighteenth dynasty and throughout the nineteenth century, royal tombs were usually located below the valley some distance from the rock walls. Builders often take advantage of their ankle slopes, as in the case of the Horemheb KV57 tomb. Indeed, many other royal tombs in the Valley of the Kings exhibited similar decay and disintegration features. Most of the royal tombs in the Valley of the Kings and the Western Valley were excavated in the limestone of the middle and lower part of the first Thebes, member, the lowest unit of the formation of Thebes. However, many tombs penetrate the rock and interlocking rocks found in the formation of Isna Shale. All show an advanced deterioration in the rock structure that is irreversible due to swelling and contraction. The Horemheb tomb KV57 is clearly more susceptible to the additional geostatic loading of overburden or surcharge heavy rock layers, rock bursts, and structural damage to support pillars and sidewalls and the effects of past/ recent rapid floods caused by torrential rains in the valley. this tomb also come into contact with underlying shale layers, which have the potential to swell and shrink in conditions of variable humidity. Extensive damage to these underground structures was widely observed in the Valley of the Kings. This tomb KV57 tends to be one of the worst tomb preserved in the Valley of the Kings. The marl shale in the valley is particularly weak and unstable. Not only did the old quarry problem come up, but the modern conservators too. When the marl shale comes in contact with moisture, it expands and can literally rip the hillside. Insufficient column strength can lead to extreme instability and failure of the adjacent rock mass with potential catastrophic consequences for the associated undergrounds.

Today, satellite imagery like Guardian (2) is systematically available free of charge for large coverage, and can 


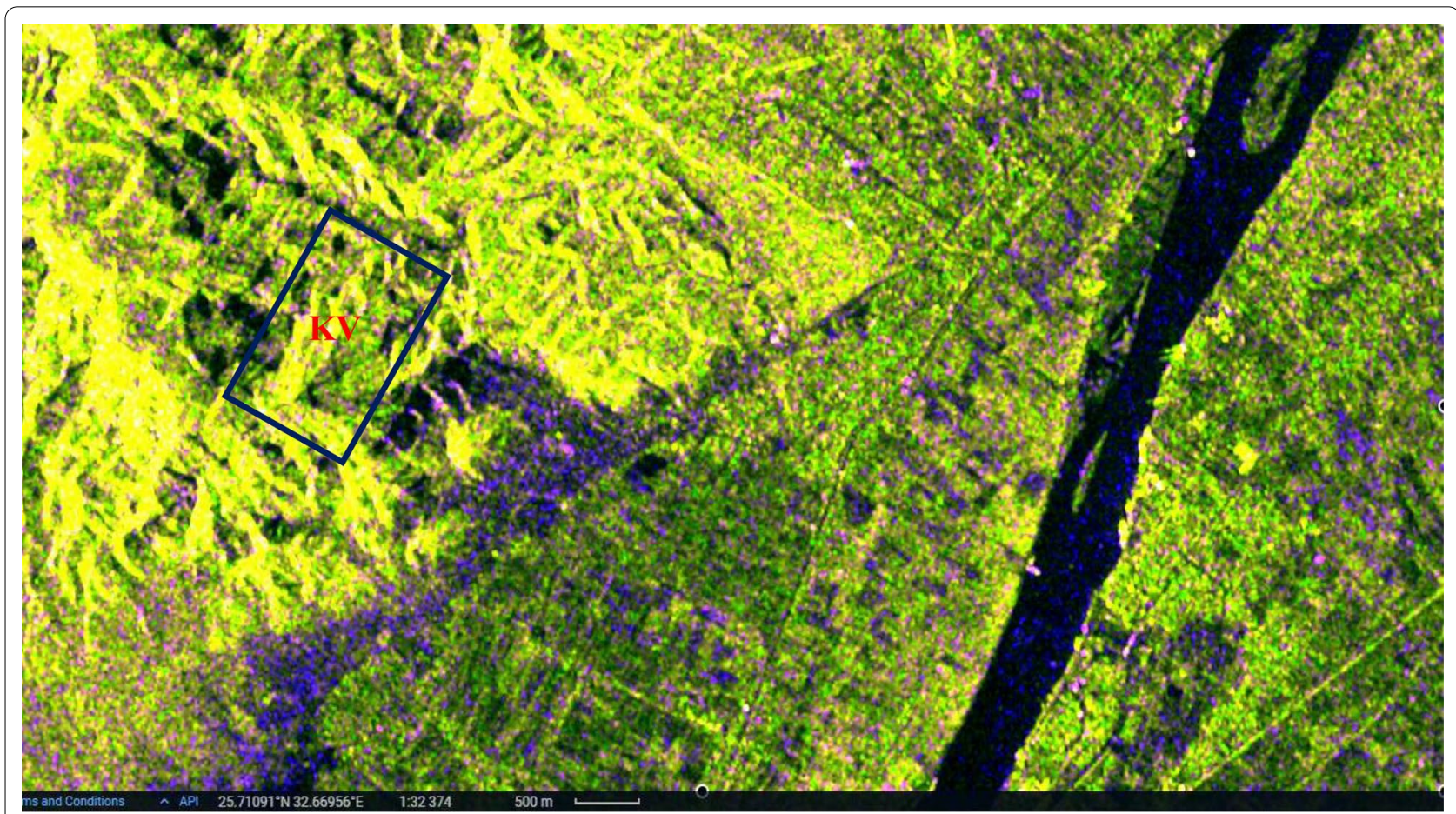

Fig. 1 LIDAR image, The Ratio "VV, VH, WVNH" combination works well for distinguishing water objects, open soils, moistened agricultural fields, vegetation, and urban areas. Water in lakes is shown in dark blue, bright blue or black hues with radar signal noise. Blue hues show agricultural fields with bare soil, often sufficiently waterlogged. Fields with vegetation show a green color. Buildings of a metropolis are represented by bright green-yellow shades

be used for accurate mapping as well as for documenting and analyzing historical and contemporary human activities around cultural heritage sites.

The paper represents the first comprehensive empirical and numerical studies to analyze the engineering failure and the appropriate design of the permanent mechanical support system for the Tomb of Horemheb (KV57). It is in fact one of the largest rock tombs found in Egypt.

The main characteristics of the geo-environmental and geotechnical analyzes conducted in this study are the investigation of the stable stability, safety margins, and engineering failure of the tomb of Horemheb (KV57) under their current conditions, against the unfavorable environment (i.e. widespread weathering due to the impact of water and sudden floods in the past and present in particular the 1994 flash flood), Complete lack of protection, geostatic overload of structural rock support pillars, and severe geotechnical and seismic conditions. Also to design a suitable geotechnical support system, according to the engineering rock block rating, in particular the RMR rock block rating and the Q-system index of highquality rock tunnel.

Engineering analysis was carried out through the following four main steps: (1) Evaluation of surrounding rocks (marl limestone and marl shale) by experimental research and Roclab program to obtain the Hoek Brown and Mohr-Coulomb fit classification criterion and rock mass standards in particular the global strength and deformation coefficient. Also to specify the main characteristics of the Esna Shale using different methods such as swelling test, swelling potential, swelling pressure, in addition, discussion of the role of the expansive Esna Shale in the deterioration of archaeological buildings and sites. (2) Quantitative and qualitative estimates of the relevant factors affecting the stability of the tomb, especially overloading, fixed, geographic, and dynamic. (3) Integrated 3D geotechnical modeling of the cemetery environment for stress and displacement analysis and identification of volumetric strains and plastic points using advanced symbols and programs such as PLAXIS 3D. (4) The rapeutic and retrofit policies and techniques and the fixed monitoring and control systems needed to strengthen and stabilize the cemetery, where the rock mass classification refers to the rock mass where KV57 is excavated and it is poor shale rocks. The mechanical behavior of the rocks is simulated by assuming a foundational model to soften the elastic stress of the flexible plastic that captures fragile failure and the mechanisms of progressive substrate failure. In addition, rock pillar treatments and ground support strategies are discussed. 
Based on the theory of stable engineering equilibrium and rock mass classification, support structure techniques are provided and detailed in detail with the KV57 case in this study.

\section{Methods/experimental}

This section includes the aim, design and setting of the present study:

\section{Remote sensing and GIS}

Earth Observation System (EOS) platform is an advanced cloud platform has been used for the search, analysis, storing and visualization of geospatial data. This digital online Platform provided efficient tools for searching, processing, and analyzing large amounts of satellite data which have been created. As a result, valuable insights allowed us to quickly respond to changes in our area of interest (KV).

ELiT (EOS LiDAR Tool) is a sophisticated product based on the complicated algorithms for urban environment modeling and analysis. It provided the original multi-functional approach to LiDAR data processing of the Valley of Kings.

(DEM), Digital Elevation Model Generation-as a representation of the bare earth terrain with uniformly spaced z-values. The DEM tool allowed us to build a Digital Elevation Model that represents the bare earth terrain of the Valley of Kings (KV). This topographic surface is exclusively based on Airborne LiDAR Point Cloud and can be obtained in a form of either DSM (Digital Surface Model) that includes buildings, woody vegetation cover, and other objects or DTM (Digital Terrain Model) with all natural and man-made objects above the ground being removed. Topographical data used in this study is the Digital Elevation Model each cell of which consists of information of X-and Y- coordinates and evaluation $\mathrm{Z}$.

\section{Geotechnical experimental and numerical analyses}

On the other hand, many samples of marl limestone and oil shale were examined, as the Tomb of Horemheb (KV57) was excavated through geological and geotechnical investigations, which include XRD, XRF, DTA-TGA analysis and thin-section examination under a polarized light microscope. Comprehensive petrophysical and mechanical testing program that includes the uniaxial pressure and velocity ultrasound velocity through materials (PUNDT) test. RocLab software was used to calculate the Hoek-Brown classification and the standard also to calculate the Mohr-Coulomb fit and rock strength parameters in the deformation modulus in particular. Underground safety analysis of the KV57 is performed using finite element (FE) method. The research provides a comprehensive study to analyze the safety of rock tombs.
Safety analysis not only includes failure analysis but the effect of weathering, in particular material corrosion on differential settlement, has been investigated. The commercial PLAXIS 3D FE package is used to perform stress, as well as stability analysis. PLAXIS 3D is a finite element software developed for the numerical analysis of geotechnical, underground and subterranean structures.

The deformation of this underground structure was calculated as realistically as possible, using an advanced nonlinear elastic material model that should be used in PLAXIS 3D capable of using such advanced models of materials. A 3D plastic model was used for deformation and incorporation analysis in this research. Consolidation analysis is performed using PLAXIS 3D. Rock mass classification calculations are used for general evaluation of the mass of the rock where KV57 was excavated. The Rock Mass (RMR) Rating results and System Q values were used to design a suitable support system.

\section{Aspects of the strengthening design of the underground monuments}

Stabilization measures may include the reinforcement and rock removal; The reinforcement may consist of rock bolting, rock anchoring, dowels, shotcrete, buttresses and drainage. The rock removal consists of resloping, trimming and scaling.

The protective measures may include the wire mesh, rock fall barriers, scaling, rock sheds and tunnels.

Strengthening design of underground monuments the following aspects are to be considered: (i)Type and purpose of the underground structures, (ii) Alignment, (iii) Site Investigation, (iv) Topographical conditions, Geological and hydrological conditions, (v) Environmental impact including, noise, vibrations and air pollution, (vi) Legal aspect, (vii) Safety requirements, (viii) Electrical\& Mechanical requirements, (ix) Geotechnical prognosis and identification of typical ground characteristics and definition of ground properties (key parameters) for analysis, (x) Risk assessment and analysis (Geotechnical Monitoring).

Geotechnical monitoring includes Typical 3D displacement measurement in the underground excavation and on the surface (if required), extensometers, sliding micrometers, inclinometers, transducers, electrical stain gauge, load cells for rock bolts, pressure cells, and piezometers are used to observe the system behavior. To enable a quick visualization, reliable evaluation and interpretation of monitoring results, special software like PLAXIS 3D is required selection of Support methods and Integration of operational systems to address the underground excavation safety requirements (ventilation, firefighting). 


\section{Historic context and architectural design of Hormheb tomb (KV57)}

This is the most creative realization that Horemheb left in Thebes, as the tomb itself is located within the western branch of the southwestern valley. The tomb hole is cut at the bottom of the hill and once inside, the way in is through a set of stairs cut from the rock. He combined his plan with a change in axis, as at the beginning of the dynasty, with a straight outline of the Amarna tombs. It has an area of about $110 \mathrm{~m}$. The sarcophagus is about $30 \mathrm{~m}$ long. Below is the entry. When approaching north from the stairs entering the burial chamber, the only deviation is in the hypostyle hall directly behind the well chamber. Here the stairs leading to the lower levels are offset to the west (opposite the western wall), but the advance is almost parallel to the upper stairs and corridors.

The burial chamber consists of two levels, the first, the upper level, which is a hexagonal hall. This leads to the lowest level, which is the actual resting place of the stone sarcophagus. Of these two sections there are nine appendices, the farthest (the farthest north) is only partially carved. The tomb was breached in ancient times. As well as digging pits through the upper passages and stairs leading to the well chamber, looters also penetrated the far wall of this chamber to reach the bottom of the tomb. The thieves are clearly not fooled by a deadly, clogged back wall.

Upon its discovery by Davis, the tomb was found to still contain many interesting items. These included red granite sarcophagus, calcite chest, and calcite. There were also many wooden statues of the gods, as well as wooden statues of the king of royal size, reminiscent of those in the tomb of Tutankhamun, but without gilding. In the chamber, known as the Chamber of Osiris, the diggers discovered the bones of two women and in the coffin, the bones of two women and another man. The remains of a man or woman were found in the coffin, which Davis was unable to identify. Horemheb's mummy has not been found and has not yet been identified, [21].

The decoration inside this tomb is organized as follows: (Fig. 2a-c) Entrance corridors and stairs (A-D): not decorated. Chamber of Well (E): Scenes with the Gods. Hypostyle Hall (f): undecorated. Corridor and stairs $(\mathrm{G}-\mathrm{H})$ : undecorated. Antechamber (I): Views with the Gods. Entering the burial chamber: the goddess Maat.

Burial Chamber-Column Hall (J1): The Book of Gates. Burial Chamber-Coffin Chamber (J1): The Book of Gates. Western Accesories (K-N): Part M ("The Room of Osiris") is undecorated. Northern polyps $(\mathrm{O}-\mathrm{Q})$ : not decorated. Oriental accessories (R-S): unadorned.

\section{State of preservation of Horemheb tomb (KV57)}

The rock slope instabilities in the valley of kings include the plane sliding, wedge sliding, block sliding, flexural toppling and rock fall where the rock column in limit equilibrium conditions are obvious. Limestone rock columns are subdivided into prismatic rock blocks of different sizes and are entirely disjointed from the rock mass behind through a system of open discontinuities. Apparently, the rock columns are in limit equilibrium conditions (near to being mobilized) due to a rock bridge in the lower portion of the same rock columns, as shown in Fig. 3.

Monuments excavated in weak rock and high overburden exhibits fracturing and large deformations due to high stresses around the opening which exceed the ground strength.

The Geotechnical instability problems and degradation phenomena of rock cut tomb of Horemheb (57) in the Valley of the Kings (KV) is likely to be dominated by gravity fall and sliding on structural features, also other factors such as excessively high rock in-situ stresses, creep effect, poor petro-physical and geo-mechanical properties of marly shale structures, weathering and /or swelling rock and flash floods caused by heavy rains in the Valley, vibrations and dynamic loading as well as utter lack of preservation become important and can be evaluated by means of a classification of rock quality. The Esna shale in the valley is particularly weak and unstable. It not only posed problems to the ancient quarryman, but to the modern conservator as well. When the shale comes into contact with moisture, it expands and can literally tear a hill side apart, [20].

The tomb was robbed in antiquity. Since then, it has been hit by at least eleven flash floods caused by heavy rains in the Valley. These have completely filled the tomb with debris and seriously damaged its comprehensively decorated walls and pillars. In October and November of 1994, two flood events occurred in the Valley of Kings, sending a warning to all heritage managers. In both cases, a local desert rainstorm occurred in the vicinity of the Valley of Kings. Storm-water runoff and sediment entered the Horemheb tomb (KV57) and other many o tombs and caused erosion of gully floors, Table 1 summarizes the he information about 1994 flood and the inundation situation inside the effected KV tombs.

Short-term effects of rainstorms on Horemheb tomb (57) included damaged wall art due to debris flows and collapsed wall structures due to water saturation. Long term damages, however, are difficult to record, even though, their impact might be more critical. Flooded tombs like KV57 built into the Esna shale Formations, are most susceptible to rock- structure deformations or deterioration due to the physical properties of the Esna shale. 


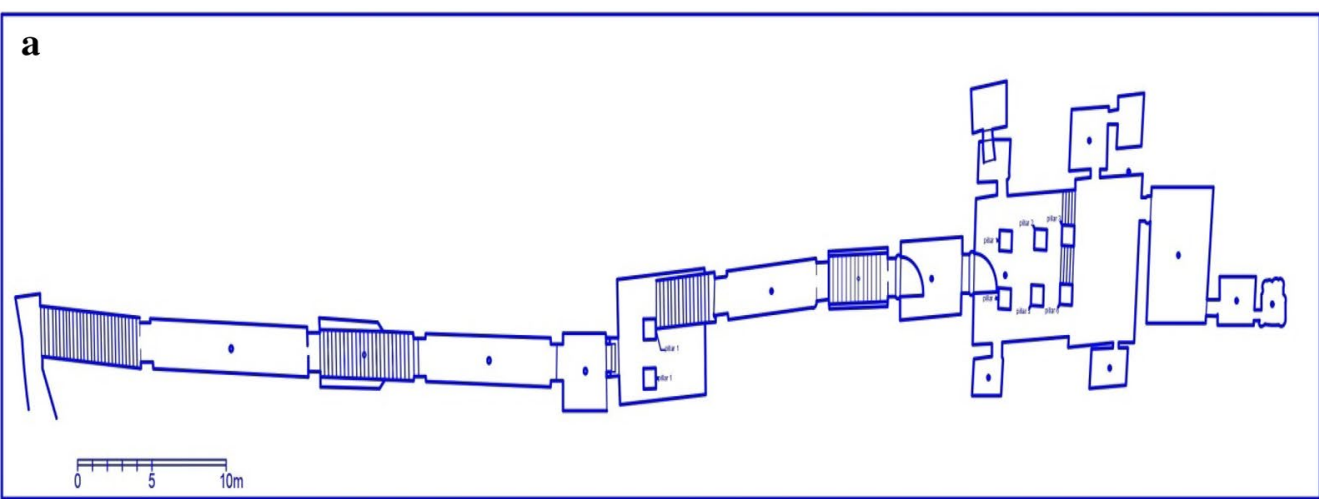

b

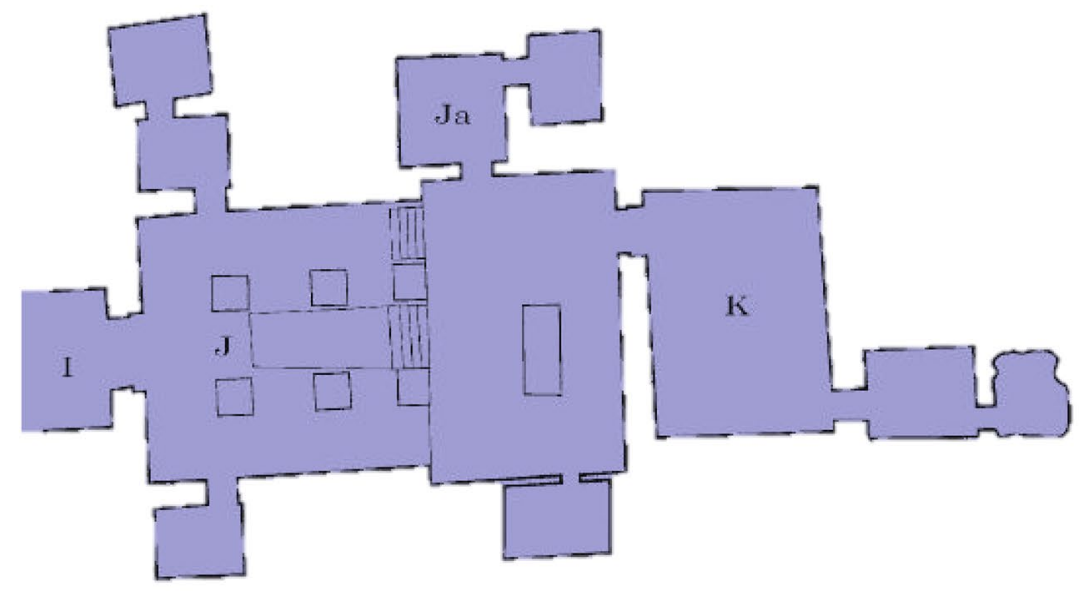

c

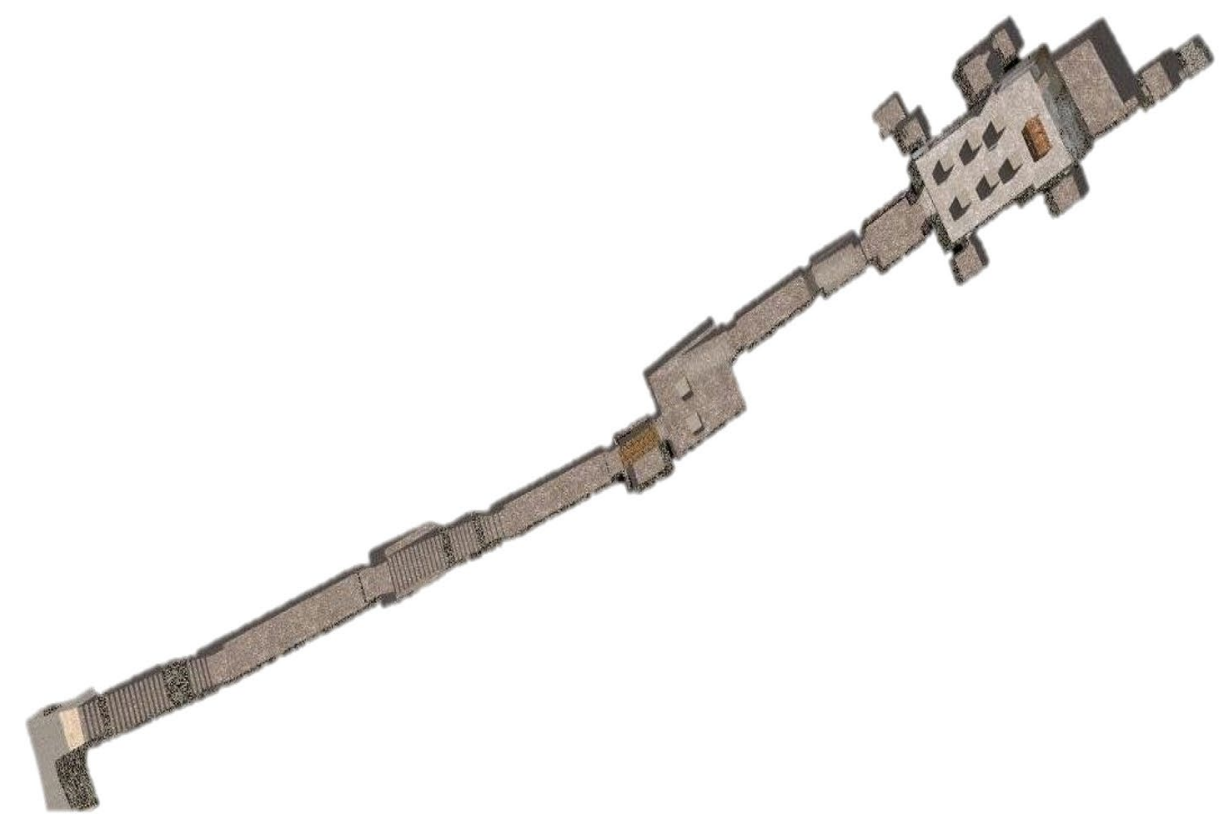

Fig. 2 a layout. of Hormoheb tomb, Valley of Kings, Luxor (KV57) with b Details of the decorated areas and c 3D Sketchup model 


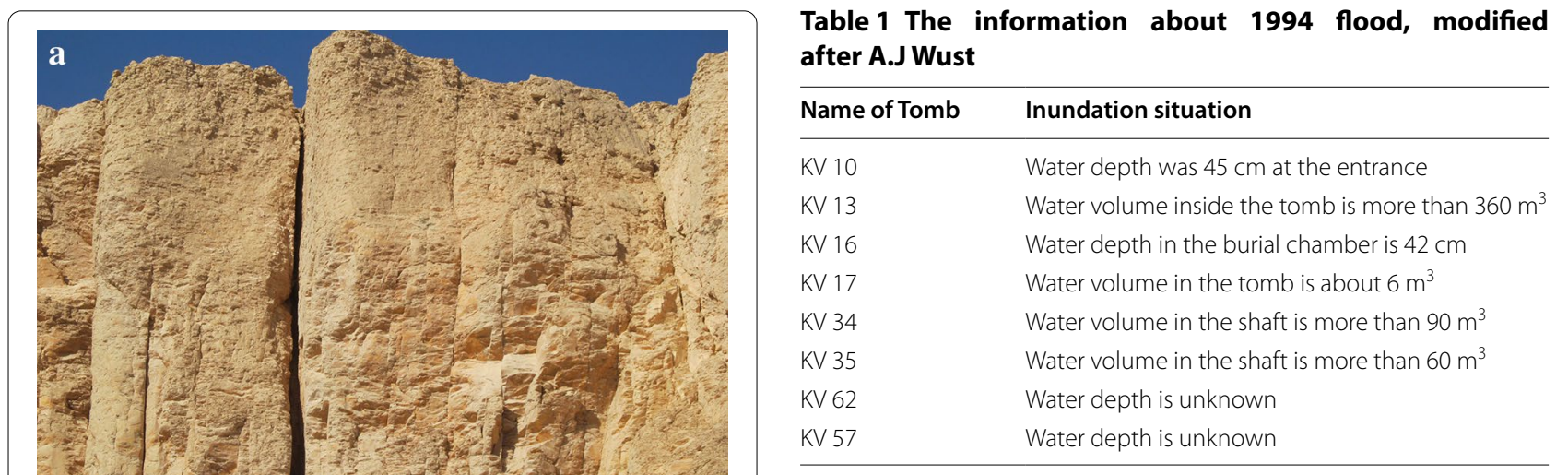

monitors show a few millimeter $(0-10 \mathrm{~mm})$ horizontal and to a more extent, vertical movements. Some parts of ceiling and walls show heavy deterioration caused by rock instability due to abundant horizontal and vertical cracks.

Figure $4 \mathrm{a}$ represents the entrance and the main corridor of the Hormoheb tomb KV57 where it is whole excavated in the marl Shale layers, Chert lenses and nodules are abundant and obvious. The In-plane deformation patterns like vertical cracks and crown zone rock falling and intensive cracking of lintel due to over loading (geostatic loading) and impact of old and modern flash floods in particular the 1994 flood, as shown in Fig. 4b. Extensive structural damage of crown ceiling zones and engineering failure of the structural pillars, sidewalls and Ceiling of the Corridors and Chambers in the KV57. Brittle rock, high stress conditions lead to rockbursting (the sudden release of stored strain energy) bursts manifest themselves through sudden. Extensive rock falls from the ceiling is obvious and cracks are active, as shown in Fig. 5. Carved and decorated walls in massive Esna shale Member are in advanced state of disintegration. Showing Chert lenses. The ornamented plaster on top of the Chert lenses and nodules was damaged during the first flash floods that entered the tomb some 3000 years ago. During several restoration projects over the past 200 years, cracks were filled with plaster for protection and stabilization of the tomb, [20]. The impact of the historical and recent flash floods on the mural paintings inside the tomb are severely obvious, as shown in Fig. 6.

\section{GEO-environmental monitoring and Assessment}

Environmental monitoring and assessment discusses technical developments and data arising from environmental monitoring and assessment, principles in designing monitoring systems, and the use of monitoring data in assessing the consequences of natural resource management and pollution risks. 
Recent improvements in Earth observation technologies offer advanced technical features that allow new applications especially for documentation, promotion, risk control and cultural heritage preservation. In particular, the latest spaceflight such as Sentinel-2, Landsate8 OLI + TIRS, Landsate7 ETM + Landsate 4-5 MSS and other satellites are particularly concerned with risk assessment and management, which is systematically acquired for the whole world.

This study provides the possibility of using these modern technological tools in terms of designing and planning the smart and sustainable use of cultural heritage resources. The survey showed that most of the environmental problems around the Valley of the Kings come from previous torrential floods due to rainstorms, high level of groundwater depth and the main reason is unplanned urban sprawl. The results of our analysis showed that the Valley of the Kings is located in the Western Desert with low rainfall and its frequency in the Nile River Basin in Egypt. Previous research suggests that storm duration exceeds one to two hours. Most of the storms have had a low intensity of rain since 1994. However, severe rainstorms have been observed in recent years due to the impact of climate change. At the moment, there is a possibility that a severe storm like one or more from 1994 may have severe consequences especially in these tourist areas. Previous research indicates that the rainfall intensity for the 1994 storm was around $16 \mathrm{~mm}$ /hour within $2 \mathrm{~h}$.

The results of our analysis using the data obtained showed the spatial dimension of the changes in urban and agricultural areas, which were clearly visible in the classification images and the extracted indicators. Sustainable management and exploitation as well as conservation and mitigation strategies are mandatory to reduce decomposition phenomena, threats and human actions that may accelerate decomposition dynamics or lead to degradation and/or significant alteration of rock graves in the KV and its "environment". In this context, remote sensing techniques can provide useful data for timely information update and documentation as well as reliable tools for systematically monitoring cultural property. The massive availability of advanced remote sensing data today has opened new and unexpected challenges for several years. In particular, for archaeological sites and landscape remote sensing, it can provide useful data not only for exploring the Earth's surface to discover sites and artifacts, but also for management, evaluation and conservation, for detecting changes as well as for assessing degradation and emerging threats, [22].

Figure 7 represents an Urban Image. This band combination also provides a "natural-like" rendition while also penetrating atmospheric particles, smoke and haze.
Vegetation appears in shades of dark and light green during the growing season, urban features are white, gray, cyan or purple, sands, soils and minerals appear in a variety of colors. The almost complete absorption of MidIR bands in water provides well defined and highlighted sources of water within the image; water is black or dark blue. Hot surfaces such as forest fires saturate the Mid-IR bands and appear in shades of red or yellow. One particular application for this combination is monitoring fires. Flooded areas should look very dark blue or black. Figure 8 represents a band combination which is good for picking out land from water. In this false color image, land appears in shades of orange and green, and water appears in shades of blue. Figure 9 represents an Index stack; it becomes readily apparent in this image stack that particular colors can be equated to different landscape features. For example, vegetation displays here as green, water as purple, and soil, rocks, and barren land as blue. Clouds also appear as a mixture of purple and magenta, so in this case these indices alone are not sufficient for differentiating clouds from water. Figure 10 represents the classification map which includes four different classes for clouds (including cirrus) and six different classifications for shadows, cloud shadows, vegetation, soils/ deserts, water and snow provision of associated quality indicators corresponding to a map of cloud probability and a map of snow probability.

\section{The geology of gebel El-Gurnah, Luxor}

The Thebes (Luxor) were deposited in a shallow deep marine environment. The lowest Paleolithic to the early Eocene periods of Western Thebes consisted of three formations: the members of Trawan, Esna, and Thebes. As shown in Fig. 11, the distinctive weathering was used to form the goodness to divide the composition of the good into four units, the first member of the fourth member. The displacement of $30 \mathrm{~m}$ of the first member associated with the rift of the Valley of the Kings is located on the right side, about $40 \mathrm{~m}$ from the tomb of Amenemis (m10), and these formations were deposited in the southern part of Tethys, and the sea connecting the Atlantic and Indian Oceans, which was closed during the collision Continental between the Alps and Africa. Figure 12 represents the digital elevation model of the Valley of the Kings and Jebel Qurna. Figure 13 Stratification in the West Bank.

Jabal Al Qurna is located $4 \mathrm{~km}$ west of the Nile, opposite the city of Luxor. The main exposed rock units at Jebel Qurna are the limestone formations of Isna Shale and Thebes. The tombs of the kings were excavated in the Theban Formations on the northern side of Jebel Qurna and the tombs of the queens were excavated on the southern side, [23]. 
The main exposed rocks of Jebel Qurna are the Esna Shale (late Paleocene-early Eocene) and the mutually compatible composition from Thebes (early Eocene).

Esna rock: The bottom $25 \mathrm{~m}$ of this formation is less calcareous, usually dark green gray, sometimes rough. The upper rocks are greyish-green, more compact and hold more gypsum. Iron oxides vary in color. There are red, yellow, brown and lemonade stones. Plaster strips run parallel to the bed planes [6], as shown in Fig. 14. This represents the sudden association of the Abu Hadd member in the Isna rock formation with the stone unit 1 of the Thebes limestone formation. The photo was taken just above the KV57 site.

The Esna rock formation is divided into four distinct stone units from top to base [10]: (1) Abu Hadd (alternation of marl and limestone basins with few periods of clay. It is lighter in color and richer in carbonates than (2) Reserve member (dark mudstone). (3) fog quarry member (dark gray rock from 0.6 to $3.7 \mathrm{~m}$ ). (4) Hanadi member (massive light gray rock).

The Theban Formation: The Theban formation in the Valley of the Kings can be divided into three members (from the base to the top), the members of Hamada, alBayda, and al-Jeer. However, the formation of Thebes above the rock. The lower part of Hammadet is made of white and chalky limestone combined with concrete stone; the middle member of Bida is made of thick agglomerate limestone, with extended flint bands parallel to the bed layers, and the upper member Al-Geer is mainly made of white limestone.

There are many faults in the southwest corner of the Valley of the Kings. It is very complex in nature. The number of faults cuts into the limestone formations of the Eocene. Typically, these breaks cause various crossslip problems and the veins around the crystal calcite have developed into the overlapping spaces. Calcite may be rigid as well as bypass structures, which provide the course more rationally than request a voucher.

Table $2 \mathrm{X}$ - ray Diffraction results showing the bulk Mineralogy of marl Shale (Calcite/ Smectite) where the Horemheb tomb (KV57) is excavated, (upper pillared hall)

\begin{tabular}{lll}
\hline Ref. Code & Mineral Name & Chemical Formula \\
\hline $01-085-0849$ & Calcite & $\mathrm{Ca} \mathrm{CO}_{3}$ \\
$01-074-3485$ & Quartz & $\mathrm{Si} \mathrm{O}_{2}$ \\
$01-075-3701$ & Dolomite & ${\mathrm{Ca} \mathrm{Mg}\left(\mathrm{CO}_{3}\right)_{2}}_{0}$ \\
$00-004-0551$ & Rutile & $\mathrm{Ti} \mathrm{O}_{2}$ \\
$00-011-0303$ & Montmorillonite & $\left(\mathrm{Al}(\mathrm{OH})_{2}\right)_{0.33} \mathrm{Al}_{2}$ \\
& & $\left(\mathrm{Si} \mathrm{Al}_{0.33} \mathrm{O}_{10}\right)$ \\
& & $(\mathrm{OH})_{2}$ \\
& &
\end{tabular}

Table $3 \mathrm{X}$ - ray Diffraction results showing the bulk Mineralogy of marl Shale (Calcite/ Smectite) from the upper Esna shale Formation, where the Horemheb tomb (KV57) is excavated, (Burial chamber)

\begin{tabular}{lll}
\hline Ref. code & Mineral name & Chemical formula \\
\hline 01-085-0849 & Calcite & $\mathrm{Ca} \mathrm{CO}_{3}$ \\
01-074-3485 & Quartz & $\mathrm{Si} \mathrm{O} 2$ \\
00-046-1311 & Muscovite-2M1, ammonian & $\left(\mathrm{K}, \mathrm{N} \mathrm{H}_{4}, \mathrm{Na}\right) \mathrm{Al}_{2}(\mathrm{Si}$, \\
& & $\mathrm{Al})_{4} \mathrm{O}_{10}(\mathrm{OH})_{2}$ \\
00-001-0993 & Halite & $\mathrm{Na} \mathrm{Cl}$ \\
\hline
\end{tabular}

Regular defects, showing evolution of the northeastwest trend plane, are abundant. However, a fatal flaw, on the northwest side of the canyon, may be the predominant (and left-handed) glide, while others require diagonal assistance (left-to-right rotation, regular right-turn rotation). Although these five measured errors are not
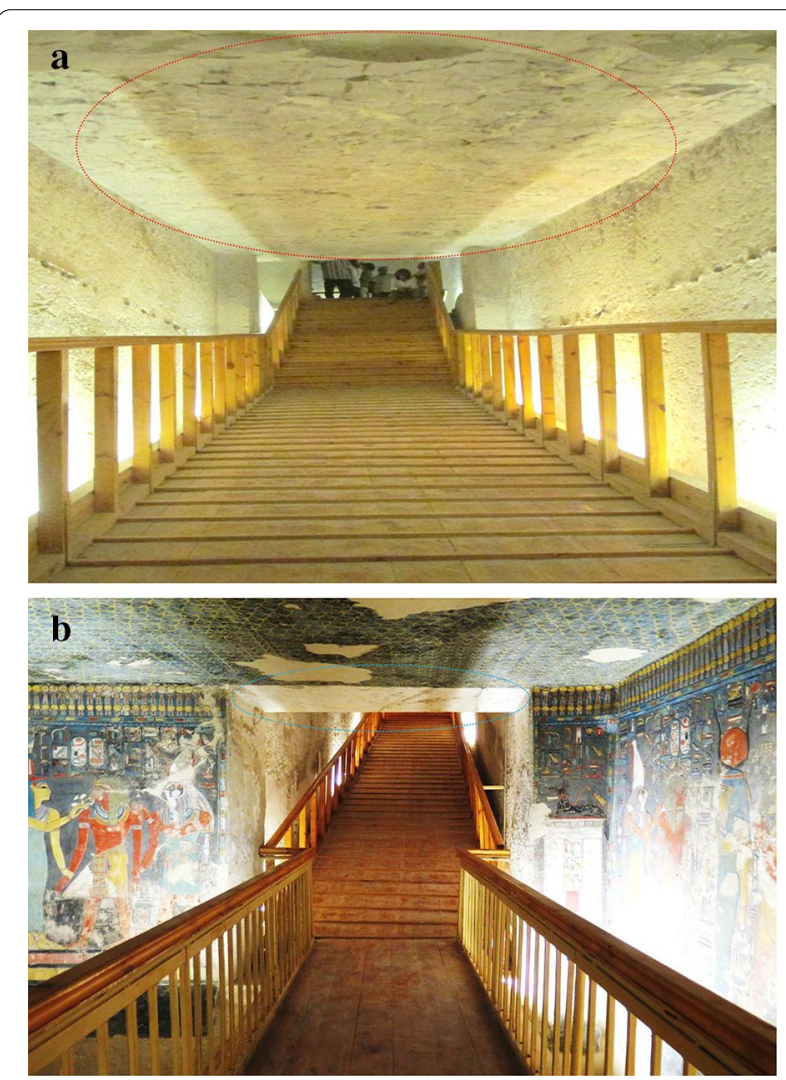

Fig. 4 a the entrance and corridor of the KV57 where it is whole excavated in the marl Shale layers, Chert lenses and nodules are abundant and obvious. b In-plane deformation patterns like vertical cracks and crown zone rock falling and intensive cracking of lintel due to over loading (geostatic loading) and impact of old and modern flash floods in particular the 1994 flood 


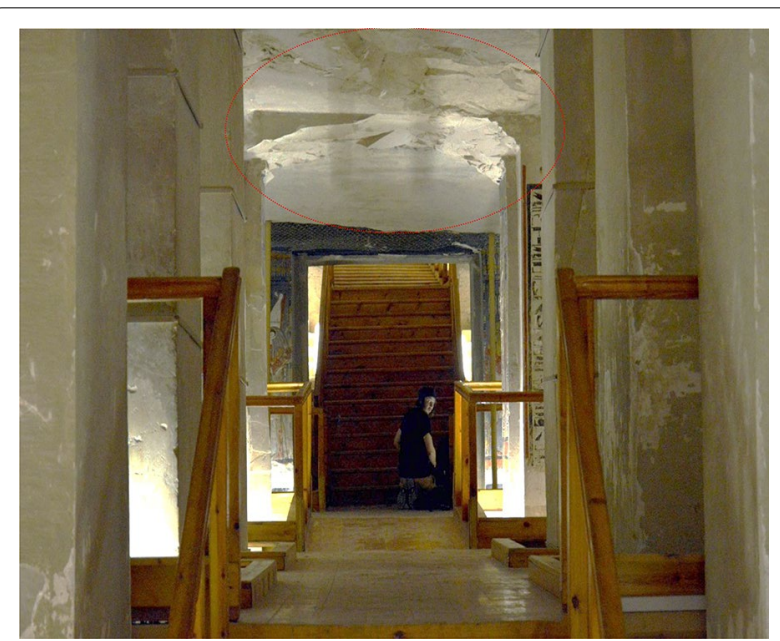

Fig. 5 Extensive structural damage of crown ceiling zones and engineering failure of the structural pillars, sidewalls and Ceiling of the Corridors and Chambers in the KV57. Brittle rock, high stress conditions lead to rockbursting (the sudden release of stored strain energy) bursts manifest themselves through sudden. Extensive rock falls from the ceiling is obvious and cracks are active wher the gypsum Pegs are cracked and broken

sufficient, they will have a chance to be statistically significant. When brittle rocks lead to high pressure conditions, the rock bursts (the sudden release of stored stress energy) that manifests itself suddenly.

Figure 15 is an indication of the erosion caused by the rapid flooding of the shale stratum and vertical fissures in Unit 1 of the limestone at Thebes, and the identification of abandoned excavations and its bridge. The semivertical wall pieces were excavated at the top of the shale formation and at the base of the limestone formation at Thebes. White arrows indicate erosion grooves at the bottom of the first unit of the Thebes Formation, in the Hanadi member (the Esna rock formation) and in the debris covering the Esna Formation. Note that the grooves in the base of the limestone at Thebes and slightly below are generally hollow, particularly at the top and bottom of the protruding base of Unit 1 . These are possible signs of a flash flood. Deciduous blocks are unstable columnar mass and open columnar fractures; Degrees. Dunes resulting from archaeological excavations, [24].

\section{Results and discussion of the experimental investigations}

Mineralogical and Geotechnical properties of intact marl limestone and marly Shale specimens and discontinuities

The tomb was cut to the south-facing side of the lower unit of the Thebes Formation.

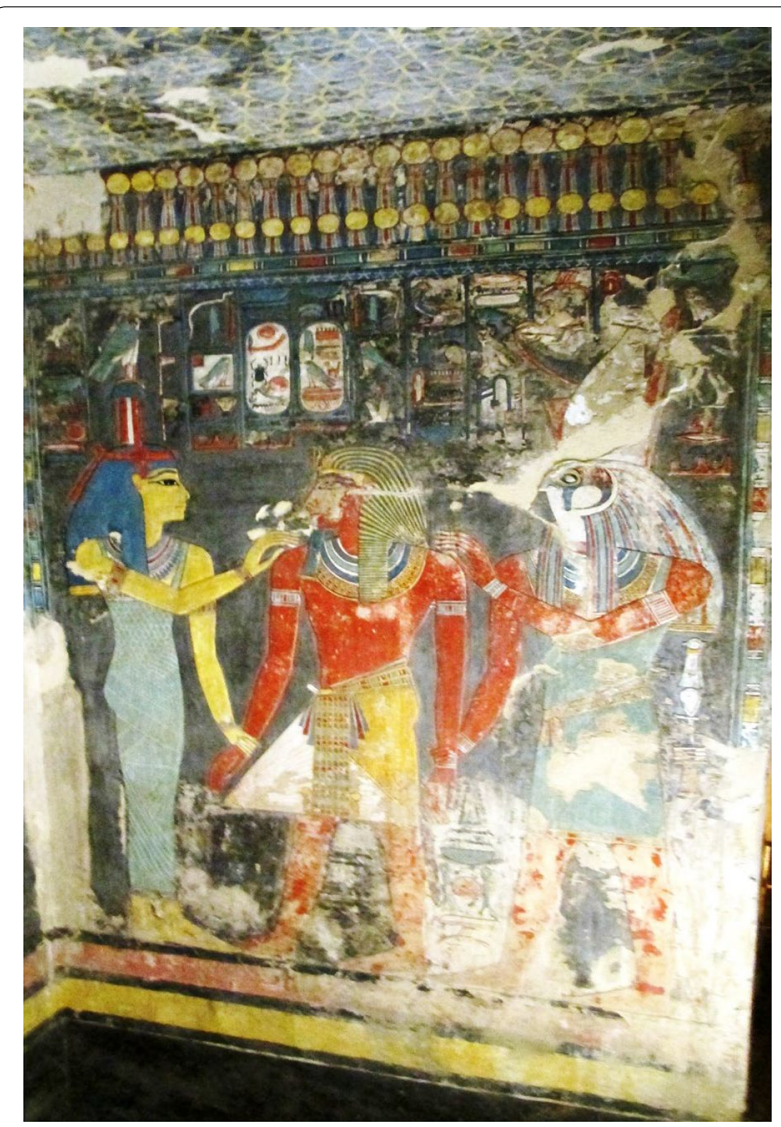

Fig. 6 Carved and decorated walls in massive Esna shale Member are in advanced state of disintegration. Showing chert lenses. The ornamented plaster on top of the chert lenses and nodules was damaged during the first flash floods that entered the tomb some 3000 years ago. During several restoration projects over the past 200 years, cracks were filled with plaster for protection and stabilization of the tomb. The impact of the 1994 flash floods on the mural paintings inside the tomb are severely obvious

The tomb is built in the Esna rock formation, at a height of $152.59 \mathrm{~m}$ above sea level.

Eight thin sections were examined with a polarized optical microscope to determine the petrographic and geochemical properties of this building material (Marl and Marly Shale limestone). X-ray diffraction (XRD) probes and an X-ray probe (XRF) were performed to determine the slices and proportions of limestone and shale. In addition to the electron microscopy (SEM) attached to energy dispersive $\mathrm{x}$-ray (EDX) for microscopy and microscopy. The XRD diffraction examples for both studied stones and slurry tests were increased by $\mathrm{Cu} \mathrm{K}$ radiation. Filtering velocity $2 \theta=1 \% \mathrm{~min}$. At a constant voltage of $40 \mathrm{kV}, 30 \mathrm{~m}$ and using X-ray diffraction PW 1480. Significant components (wt\%) of the studied 


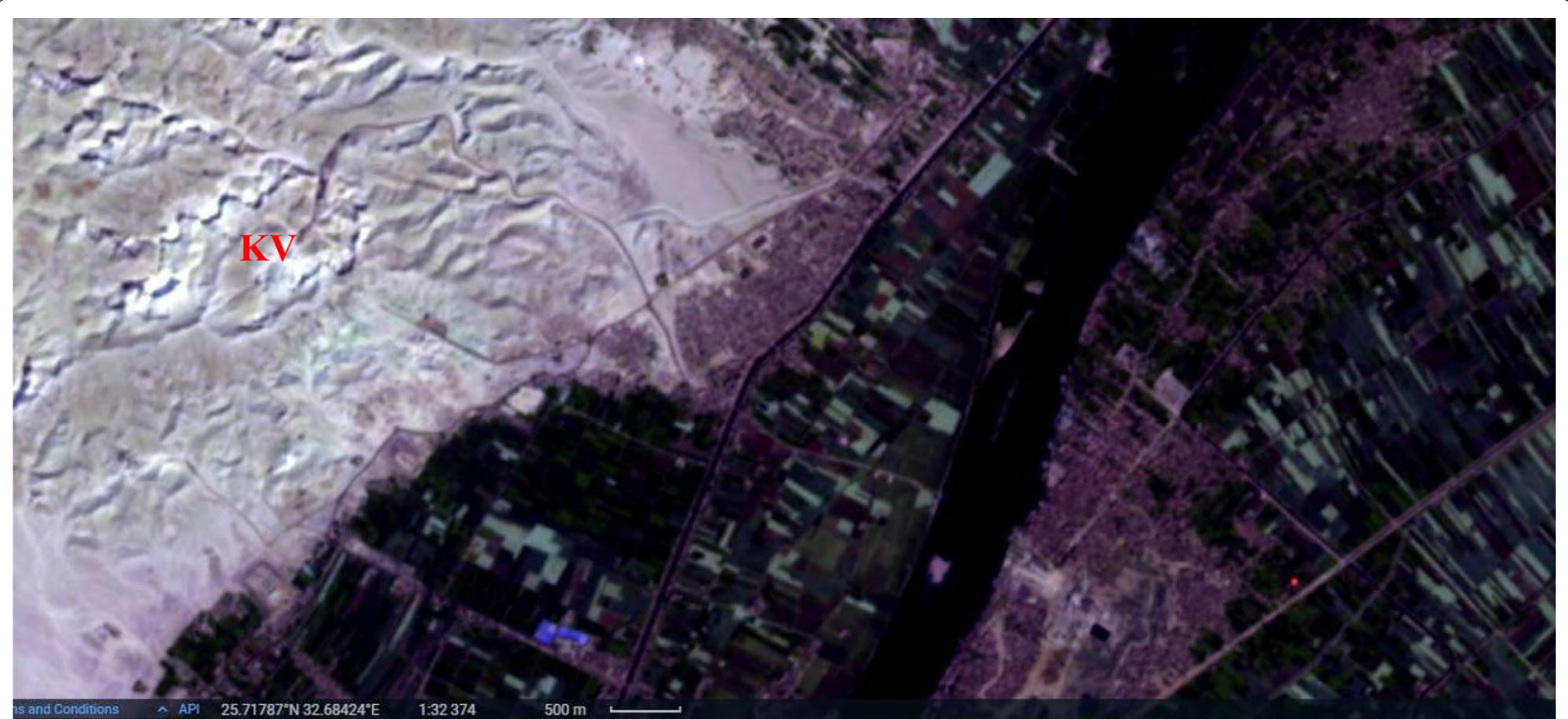

Fig. 7 Urban Image. This band combination also provides a "natural-like" rendition while also penetrating atmospheric particles, smoke and haze. Vegetation appears in shades of dark and light green during the growing season, urban features are white, gray, cyan or purple, sands, soils and minerals appear in a variety of colors. The almost complete absorption of Mid-IR bands in water provides well defined and highlighted sources of water within the image. water is black or dark blue. Hot surfaces such as forest fires saturate the Mid-IR bands and appear in shades of red or yellow. One particular application for this combination is monitoring fires. Flooded areas should look very dark blue or black

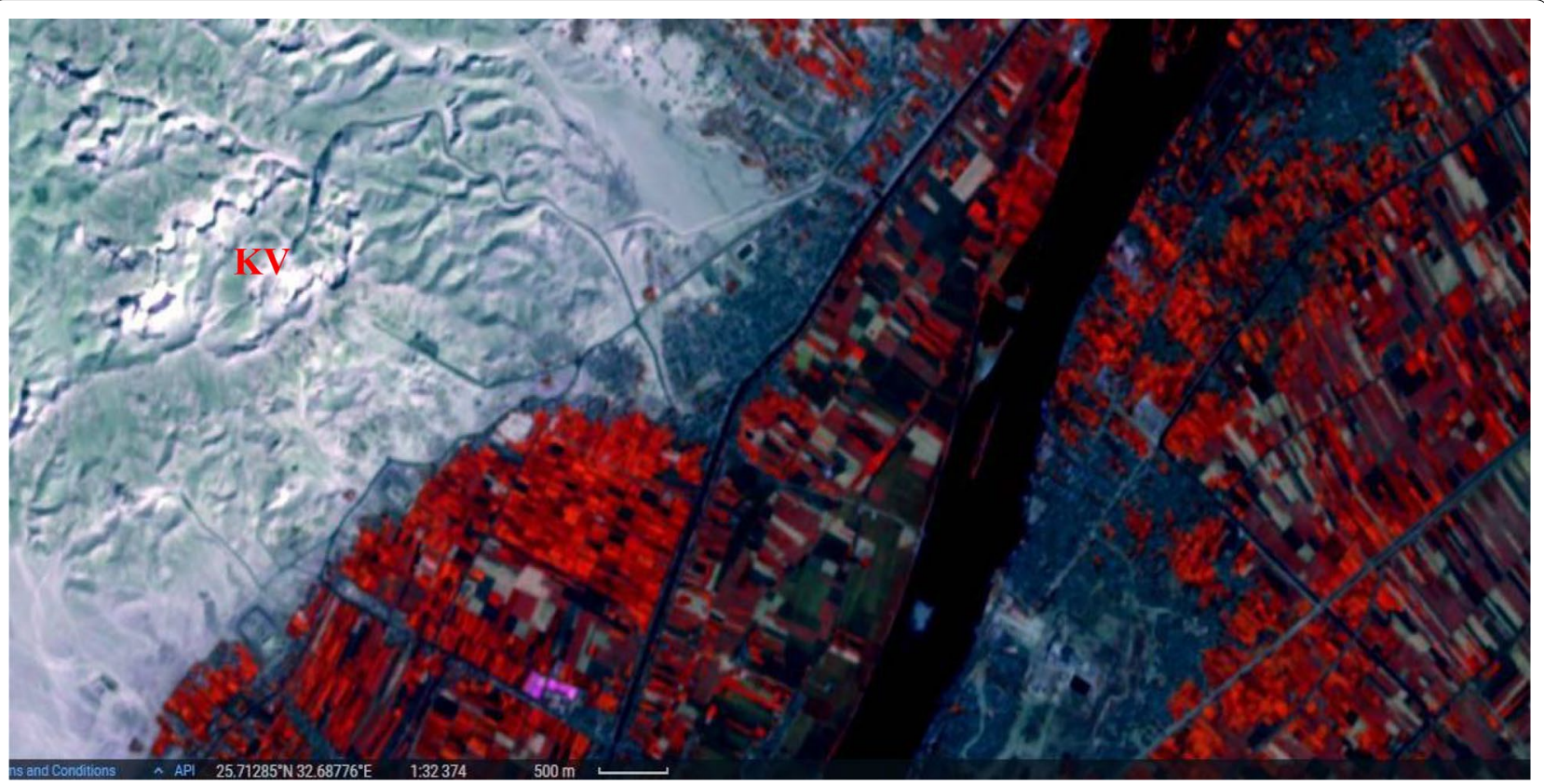

Fig. 8 This band combination good for picking out land from water. In this false color image, land appears in shades of orange and green, and water appears in shades of blue

stones and rocks tests were performed using X-ray spectroscopy (XRF) with an advanced wavelength-dispersion spectroscopy (Axios, WD-Spectrophotometry) XRF,
PANalytical, 2005, Netherlands). Chemical analyzes were performed using ASTM specifications [ASTM C11400, (ASTM C114-15)], and electron microscopy (SEM) 


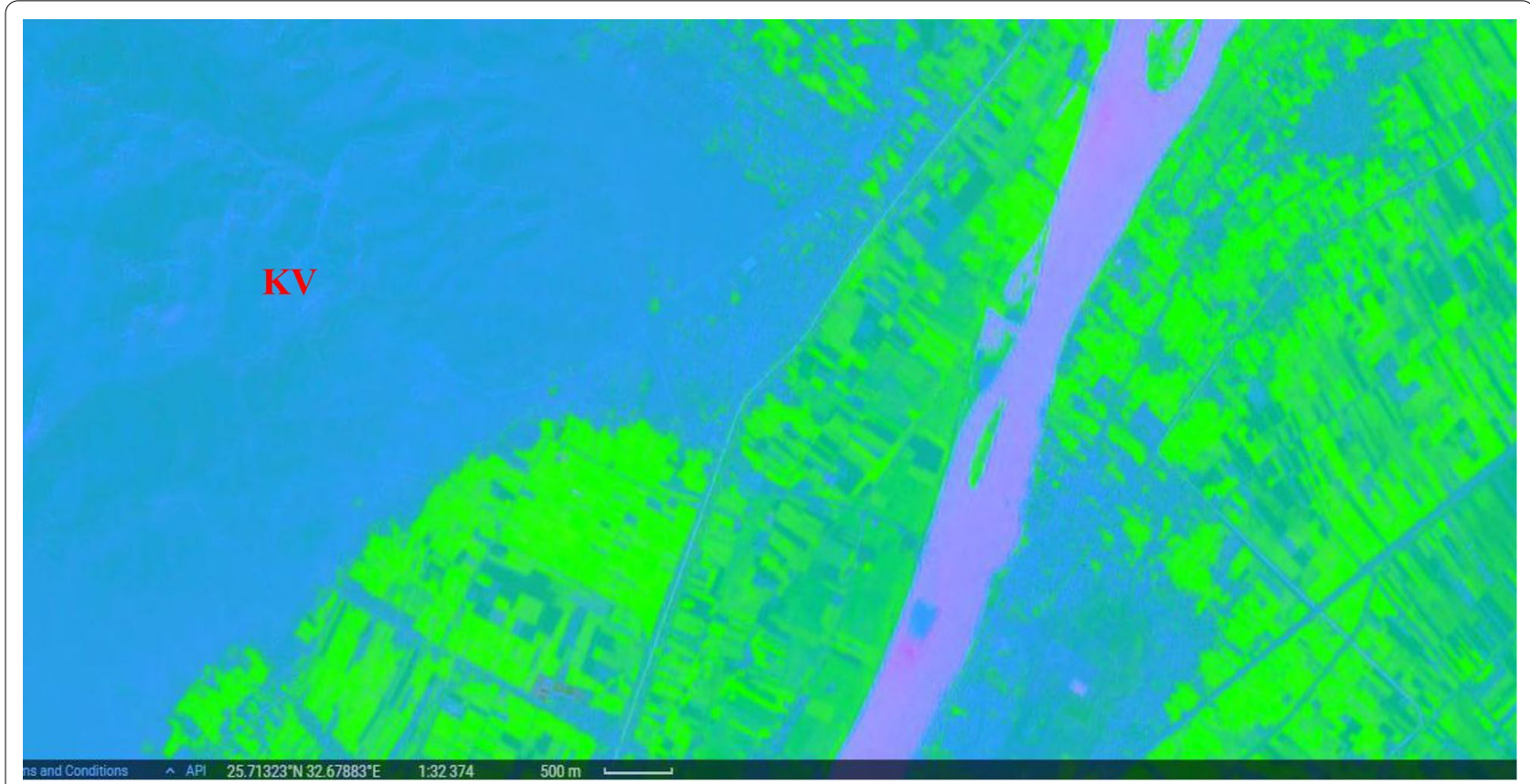

Fig. 9 Index stack. It becomes readily apparent in this image stack that particular colors can be equated to different landscape features. For example, vegetation displays here as green, water as purple, and soil, rocks, and barren land as blue. Clouds also appear as a mixture of purple and magenta, so in this case these indices alone are not sufficient for differentiating clouds from water

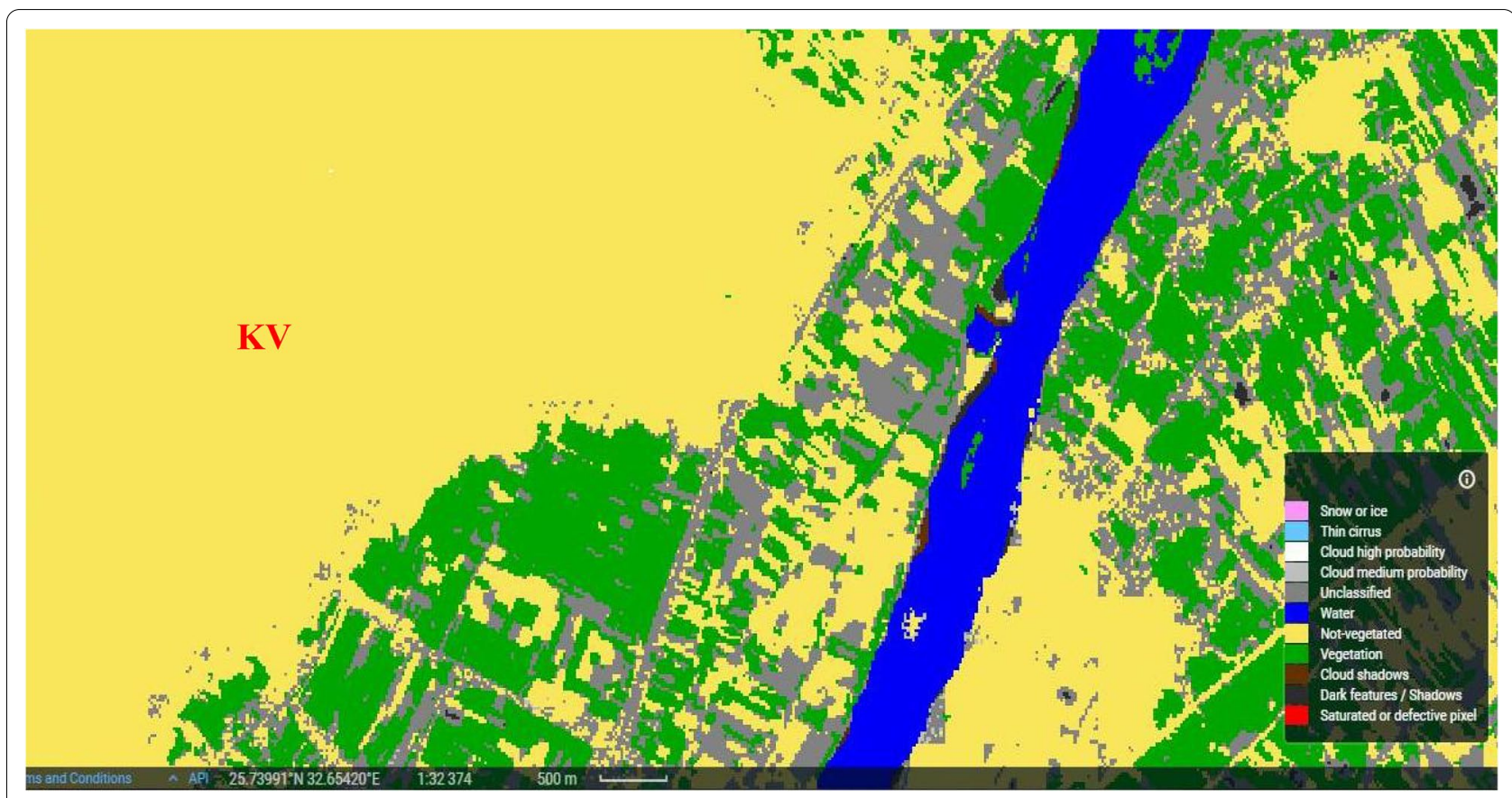

Fig. 10 The classification map which includes four different classes for clouds (including cirrus) and six different classifications for shadows, cloud shadows, vegetation, soils/deserts, water and snow provision of associated quality indicators corresponding to a map of cloud probability and a map of snow probability 


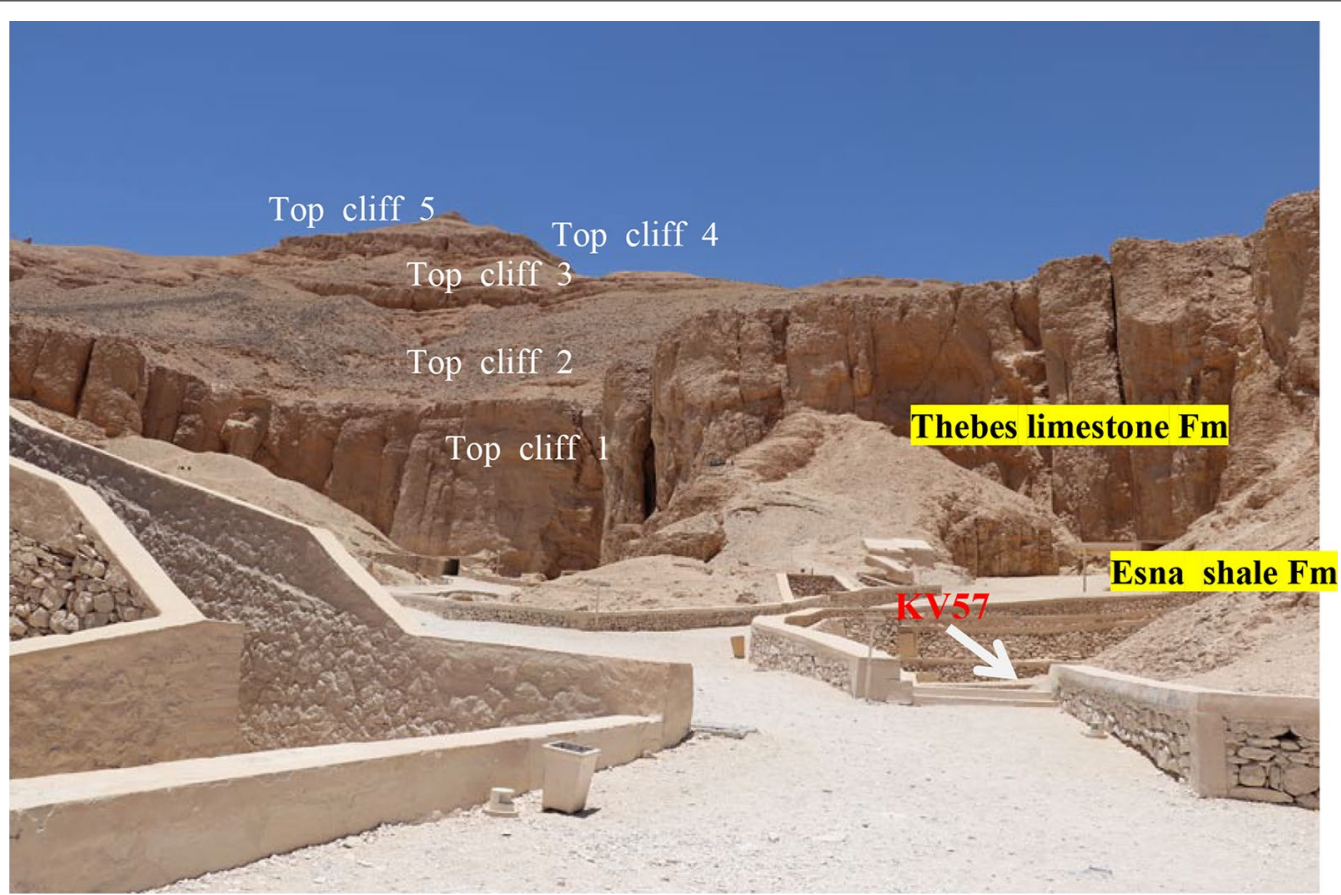

Fig. 11 Location of the Horemoheb tomb (KV57) at the east (main) Valley of the Kings (KV), Luxor Egypt. Stratigraphical succession as seen. Characteristic weathering of the Thebes Formation was used to subdivide the Thebes Formation into four units, Member I to Member IV. A 30 m displacement of Member I associated to the Kings Valley Fault is located on the right-hand side approximately $40 \mathrm{~m}$ from the tomb of Amenmesse (KV10)

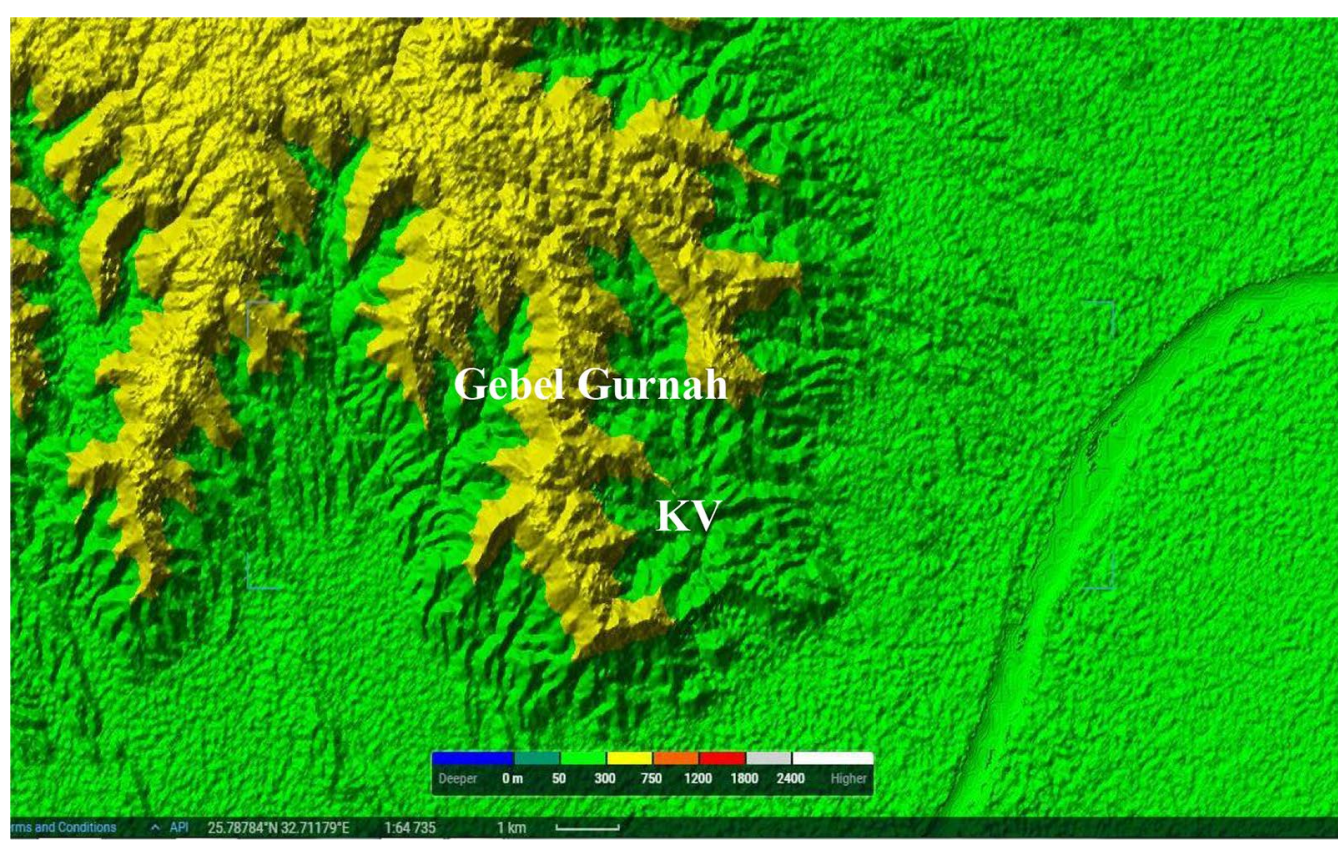

Fig. 12 (DEM), Digital Elevation Model of the valley of kings and the Gebel Gurnah 


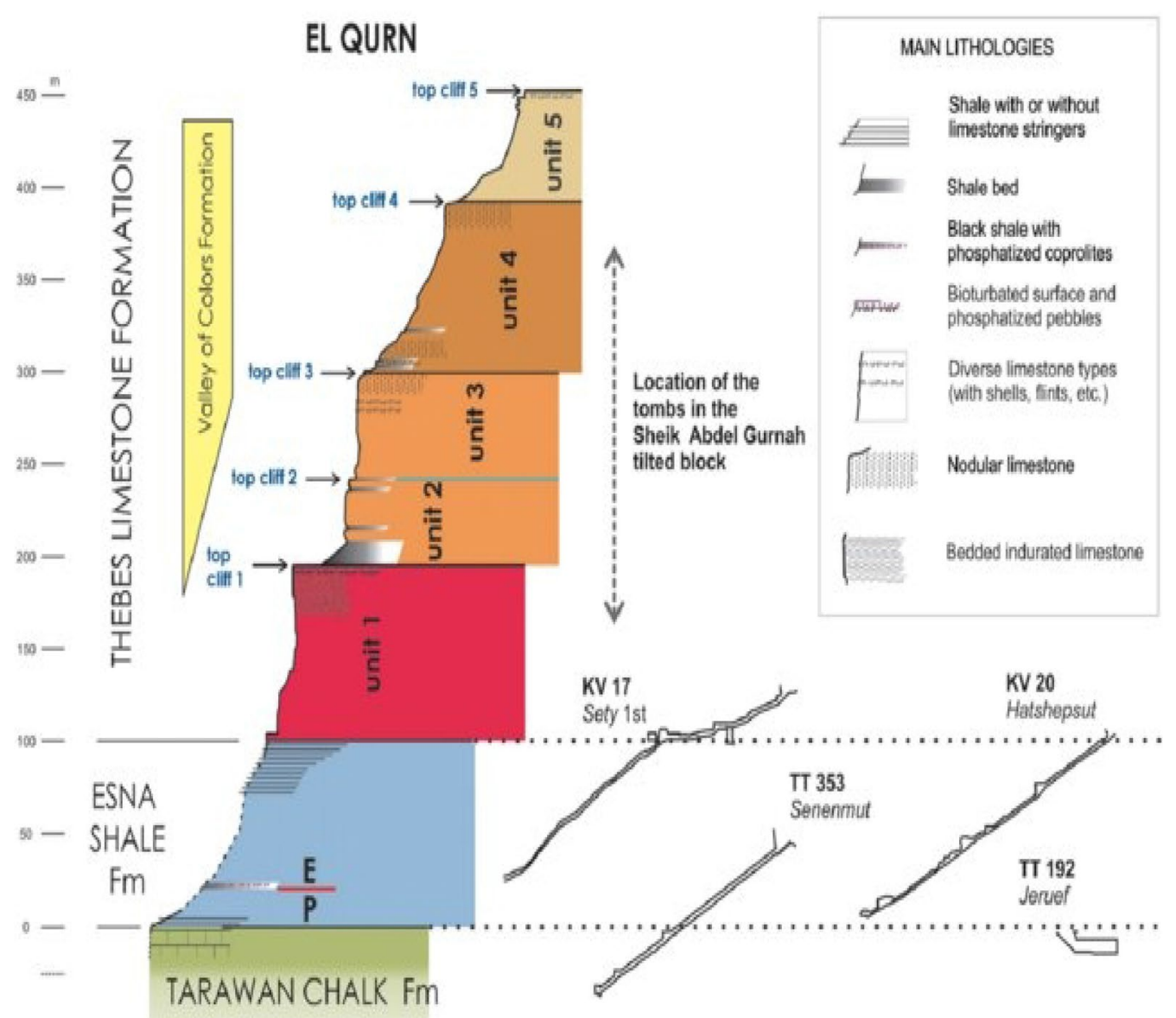

Fig. 13 Stratigraphical succession on the West Bank. We show here the location of selected tombs in this succession. Tombs KV17, 20, TT353 and 192 are located in the sub horizontal bedrock. P, Paleocene; E, Eocene

images were performed on smaller JXA 840A electron test analyzer, Japan,

The engineering properties of the studied building materials were realized. Thirteen cylindrical samples were prepared from limestone and shale to determine the petrophysical and geochemical properties. Specific gravity (Gs), bulk unit weight $(\gamma \mathrm{b})$, water absorption $(\mathrm{Wc})$, porosity (n) and saturation (Sr) are the specific physical aspects. While the mechanical characterization includes determination of the uniaxial compressive strength (c), Young's modulus (E) and discrete Brazilian tensile strength $(\mathrm{t})$, shear cutting $(\mathrm{T})$, and Schmidt Hammer index (SHV), force or impact indicators are estimated by AIV, in addition to Non-destructive ultrasound velocity $(\mathrm{Vp})$ test with volumetric examples, Young's dynamic modulus (Edy) and shear modulus (G).

\section{Mineralogical study}

The Esna Shale II upper unit consists of interlocking layers of marl and shale. The marls of Esna Shale II and marls of Member I have similar combinations. Marl Esna Shale II contains $65-70 \%$ Calcite and $30-35 \%$ clay minerals.

The clay minerals consist mainly of palygorskite (50$80 \%)$, kaolinite $(10 \%)$ and mixed layers of Illite/smectite $(10-40 \%)$. The mineral composition of shale is $5-25 \%$ calcite, $5-10 \%$ anhydrite and $70-80 \%$ clay minerals. Clay minerals consist mostly of mixed layers of lit/smectite (40-75\%), yogorskite (20-50\%), kaolin (less than 10\%) and elite (less than 10\%). The bottom unit of Esna's composition, Esna Shale I, contains up to 20\% Calcite and up to $95 \%$ phosilicate, with $3-10 \%$ anhydrite. Clay minerals consist of about 70\% kaolin, 25-35\% illite/smectite mixed layers and small amounts of palygorskite and elite, as shown in Fig. 16. 


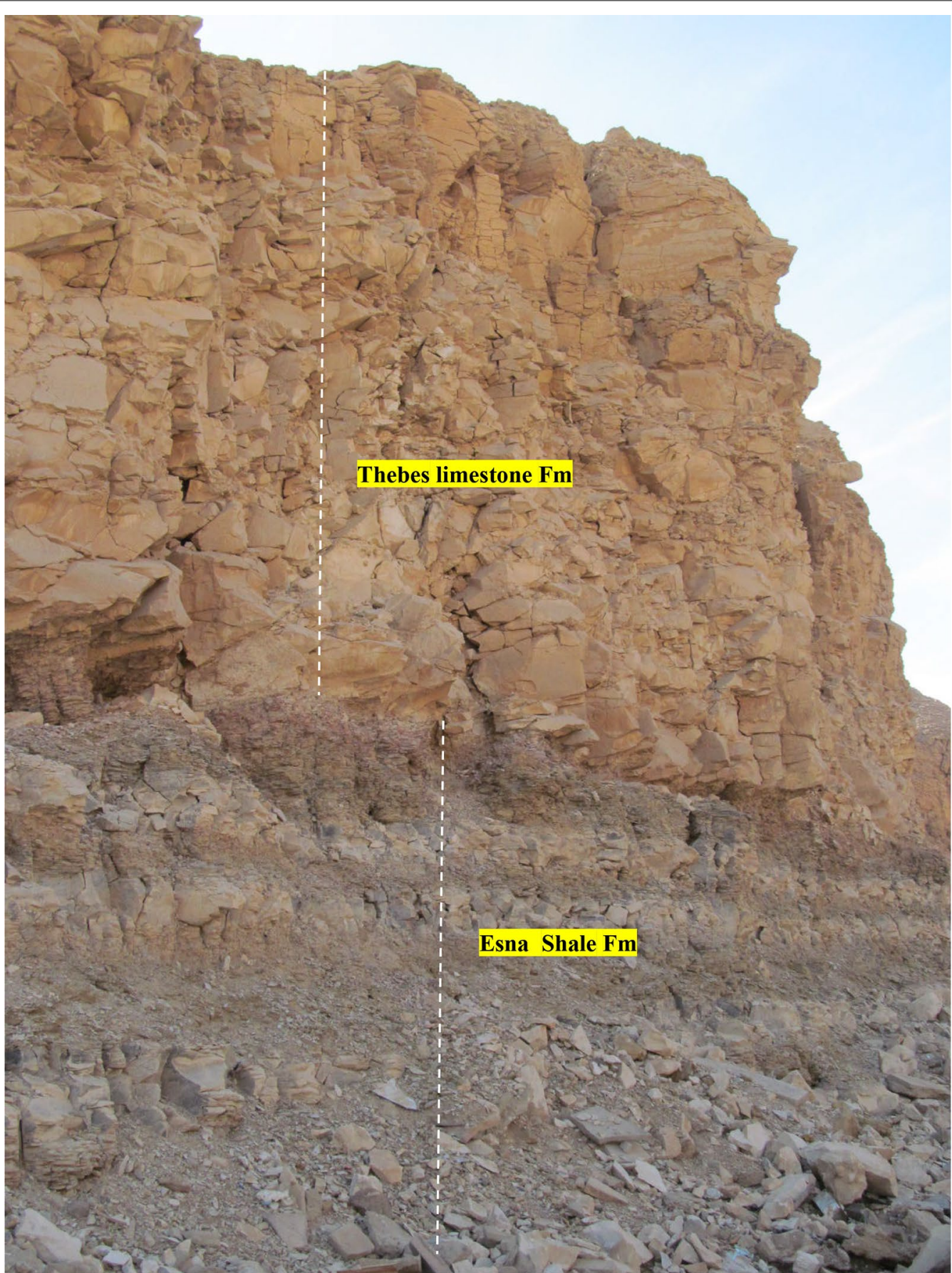

Fig. 14 Abrupt contact of the Abu Had Member of the Esna Shale Formation with lithological unit 1 of the Thebes Limestone Formation. Photo taken just above the location of the KV57

In the four samples analyzed, the minerals calcite (marl) and clay (shale) were present in small quantities of quartz. The clay minerals discovered are smectite, palygorskite and sepiolite. Clay minerals make up to $80 \%$ of the mineral composition in shale.
Small amounts of quartz, abundant palygorskite and little sibiolite were detected in the lower marl of the first organ. The clay mineral composition is $10 \%$ sepiolite and $90 \%$ yogorskite. 

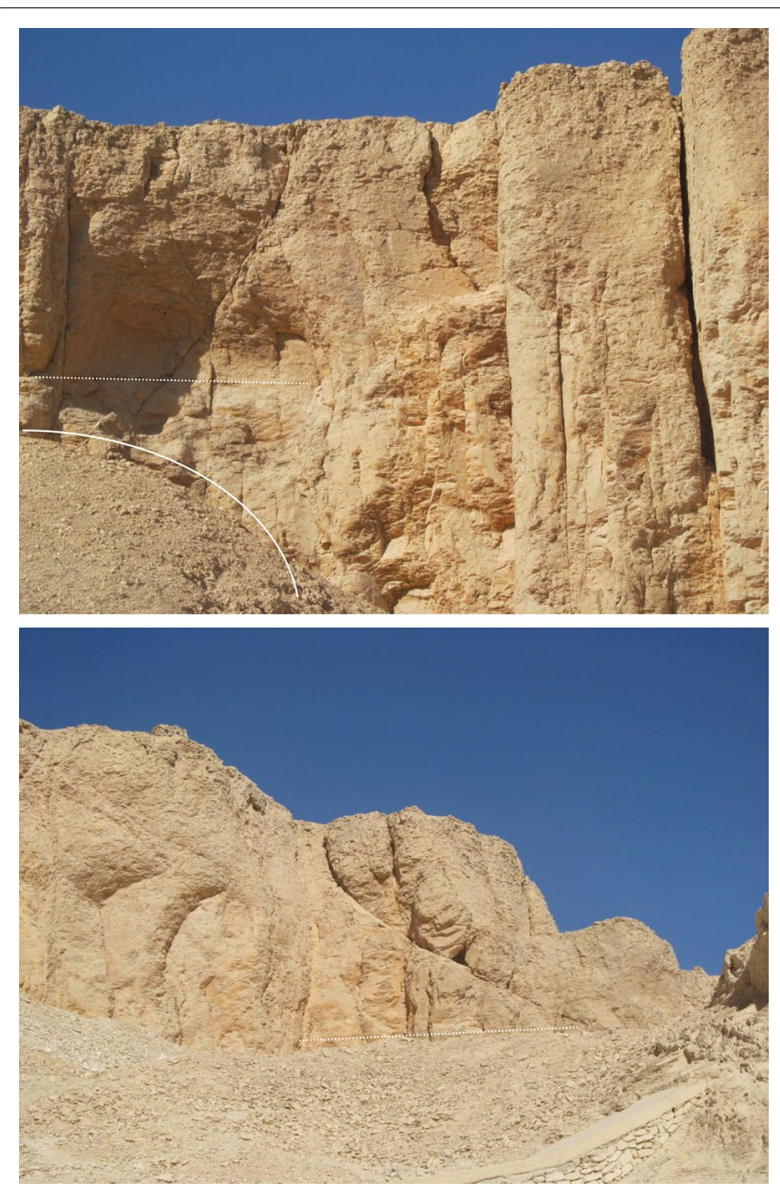

Fig. 15 Evidence of flash flood related erosion in the Esna Shale and vertical fissures in Unit 1 of the Thebes Limestone, delineation of the abandoned Excavations and its causeway. The subvertical wall-cuts were dug in the upper part of the Esna Shale Formation and at the base of the Thebes Limestone Formation. White arrows point to erosional gullies in the lower part of unit 1 of the Thebes Formation, in the Hanadi Member (Esna Shale Formation) and in the debris that cover the Esna Formation. Note that the gullies at the base of the Thebes Limestone and just below are commonly hollowed out, in particular on top and below the prominent base of Unit 1. These are probable evidence of flash floods. fallen blocks; unstable columnar block and open vertical fissures; screes. screes resulting from archeological excavations

XRD analysis indicated that the main contents of Esna shale are quartz $\left(\mathrm{SiO}_{2}\right)$ and montmorillonite $(\mathrm{Na} 0.2 \mathrm{Ca} 0.1$ $\left.\mathrm{Al}_{2} \mathrm{Si}_{4} \mathrm{O} 10(\mathrm{OH})_{2}\right)$. $\left(\mathrm{H}_{2} \mathrm{O}\right) 10$, the secondary contents include kaolinite and elite with traces of calcite, such as shown in the two Tables 2 and $3 \mathrm{X}$-ray diffraction results showing natural clay minerals or with air An untreated clay fracture sample from the Esna rocky organ, where the tomb of Horemheb (KV57) was excavated and it is a $77 \%$ montorillonite, Elite $20 \%$ and kaolinite 3\% as shown in the Fig. 17 and Table 4 and Table 5 summarizes X-ray diffraction results for three samples of oil shale in the three levels of the ESNA rock member at the KV57 site. Figure 18 represents XRD for air-dried, ethylene glycol treatment, and heated to 550 degrees Percentages of clay fractions from samples from Esna moss, demonstrating the decrease and disappearance of the Illite/Smectite (I/S) peak and the Montimorillonite present.

Eight thin sections were prepared on marl limestone and Esna shale samples where KV57 was excavated. C. The micrograph shows that the marl sample from the first organ is very fine to fine grains. Large quantities of cavities and microvienlets filled by recrystallized dolomite were observed in micritic calcite matrix. The rocks are highly grainy and consist mainly of calcite and dolomite as basic components associated with a small amount of clay minerals and rare quantities of microcrystalline quartz, iron oxides and harsh substances. Calcite represents the matrix of the rock and occurs in the form of very fine grains (microtes), from hydration to interlocking crystals below the surface. Dolomite forms very finely into fine-grained, uhedral crystals into subsurface crystals and fills in micronanoparticles and cavities. The quartz is revealed as fine-grained crystals spread throughout the matrix. Some pores of irregular shapes and different sizes are observed scattered in the rock. Some parts of the sample were stained with iron oxides, as shown in Fig. 19. C. The micrograph shows that the sample Esna shale is very fine to fine grains (mainly the size of sand), and has been well screened which is stabilized with small quantities of iron oxides, clay minerals and carbonates. The sample is porous as porous areas of different sizes are observed. The rock is mainly composed of quartz and feldspar grains that have been encrusted with small quantities of iron oxides, clay minerals and calcite. Rare amounts of muscovite, biotite, hornblende, and opaque minerals were observed in the sample. Quartz occurs as very fine sub-type grains of angular shape. Feldspar occurs as fine grains that are observed in different parts of the sample. Opaque minerals appear as fine-grained crystals spread throughout the sample. Some parts of the sample were stained with traces of iron oxides, as shown in Fig. 20.

\section{Geotechnical study}

Marl limestone: petroleum-physical properties: physical measurements indicated that the unit weight $(\gamma)$ of KV57 marl limestone ranged between 20 and $21 \mathrm{kN} / \mathrm{m}^{3}$, water absorption (Wa) between 10 and $12 \%$ and apparent porosity $(\mathrm{n})$ ranged from between 14 and $19 \%$.

Prima wave velocities (Vp): The prima wave velocities of limestone samples were measured by PUNDT 


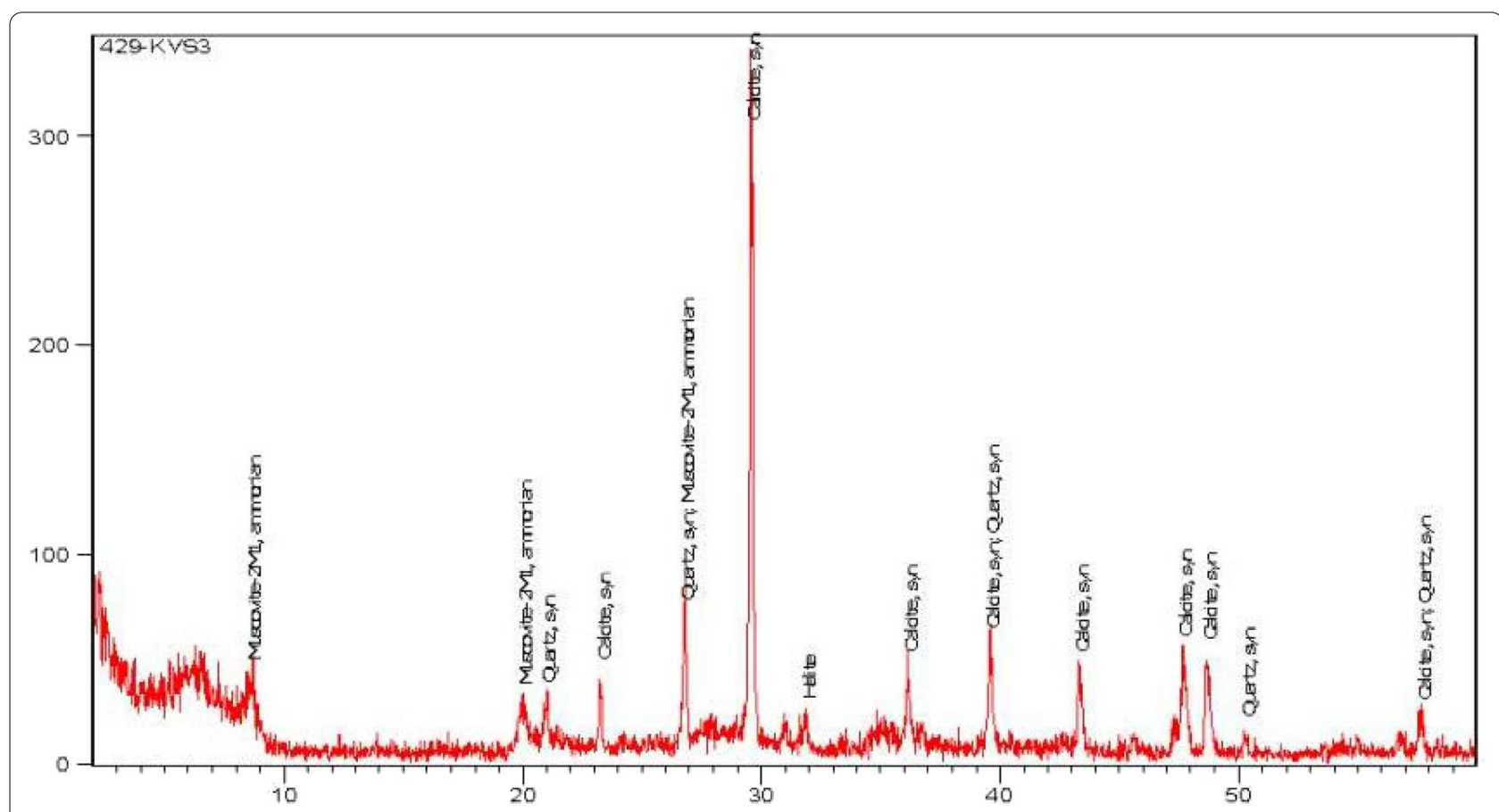

Fig. 16 X-ray Diffraction results showing the bulk Mineralogy of Marl Shale (Calcite/ Smectite) where the Horemheb tomb (KV57) is excavated

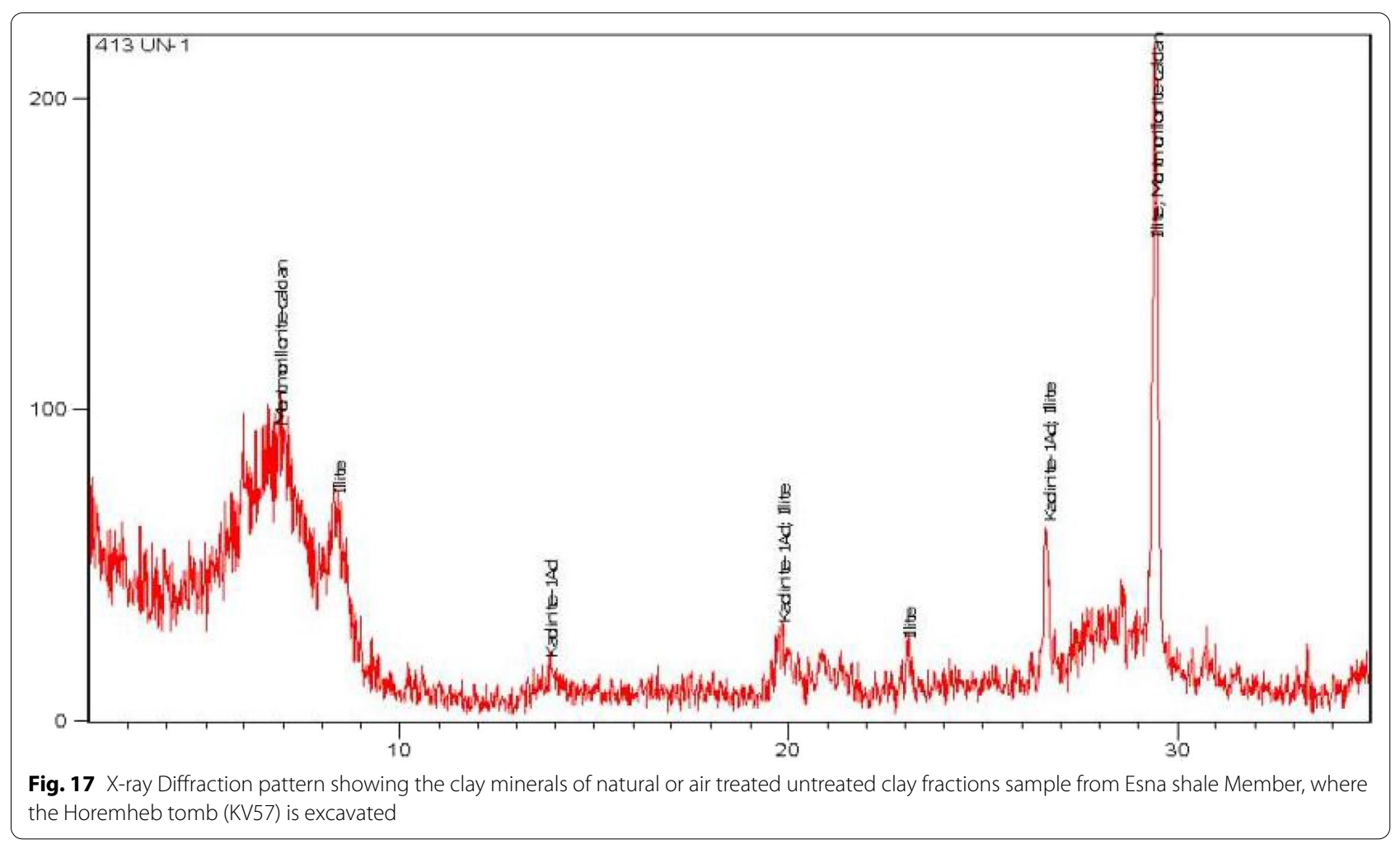


Table $4 \mathrm{X}$ - ray Diffraction results showing the clay minerals of natural or air treated untreated clay fractions sample from Esna shale Member, where the Horemheb tomb (KV57) is excavated

\begin{tabular}{lllc}
\hline Ref. code & Mineral name & Chemical formula & $\begin{array}{c}\text { SemiQuant } \\
\text { [\%] }\end{array}$ \\
\hline $00-058-2006$ & Kaolinite-1Ad & $\mathrm{Al} 2 \mathrm{Si} 2 \mathrm{O} 5(\mathrm{O} \mathrm{H}) 4$ & 3 \\
$00-015-0603$ & Illite & $\mathrm{K}(\mathrm{Al} \mathrm{Fe})_{2} \mathrm{Al} \mathrm{Si}_{3} \mathrm{O}_{10}(\mathrm{O} \mathrm{H})_{2} \cdot \mathrm{H}_{2} \mathrm{O}$ & 20 \\
$00-058-2009$ & Montmorillonite-calcian & $\mathrm{Ca}_{0.2}(\mathrm{All}, \mathrm{Mg})_{2} \mathrm{Si}_{4} \mathrm{O}_{10}(\mathrm{OH})_{2} \cdot \times \mathrm{H}_{2} \mathrm{O}$ & 77 \\
\hline
\end{tabular}

Table 5 X- ray Diffraction results of three shale samples from Esna shale Member at the site of KV57

\begin{tabular}{llll}
\hline Sample no & Major cont & Minor cont & Trace cont \\
\hline 1 & Quartz, Montmorillonite & Kaolinite, Illite & Calcite \\
2 & Quartz, Montmorillonite, & Kaolinite & $\ldots . .$. \\
3 & Quartz, Montmorillonite & Kaolinite, Illite & $\ldots . .$. \\
\hline
\end{tabular}

(ASTM 597, ASTM D 2845-83). It ranged from 700 to $900 \mathrm{~m} / \mathrm{s}$ (with an average of $1 \mathrm{~km} / \mathrm{s}$ for the direction perpendicular to the level of the mattress.

Five samples were equipped with electric strain gauges with a length of $100 \mathrm{~mm}$. Vertical pressure was gradually increased pressure until failure.

Uniaxial stress test: The compressive strength (c) of the side walls is between 8 and $9 \mathrm{MPa}$.
Young's modulus constant $(\mathrm{E})=12 \mathrm{GPa}$, Poisson's ratio $(v)=0.25-0.30$, the results are summarized in Table 6. According to the ASTM C 170, C 880, C 99 test methods and ASTM C568/C568M-15 specifications. The physical and mechanical characteristics of the construction materials is low, since the standard requirement for the uniaxial compressive strength $(\sigma c)$ of the limestone must be in range of $12 \mathrm{MPa}$ for the low density limestone to $55 \mathrm{MPa}$ for the high density limestone. The physical and mechanical properties of the construction materials are retreated because the area was subjected to intensive and flash floods.

Esna shale rock: includes physical properties, bulk unit weight of Esna rock from 1.79 to $1.86 \mathrm{~g} / \mathrm{cm}^{3}$, uniaxial compressive strength is 4.22 to $4.43 \mathrm{~kg} / \mathrm{cm}^{2}$, specific gravity $\mathrm{GS}=2.7$, void ratio ei $=1.86, \gamma \mathrm{d}=-1718 \mathrm{~N} / \mathrm{m}^{3}$, $\gamma \mathrm{b}=18-20 \mathrm{~N} / \mathrm{m}^{3}$, water content $8-10 \%$, OMC $14-16 \%$,

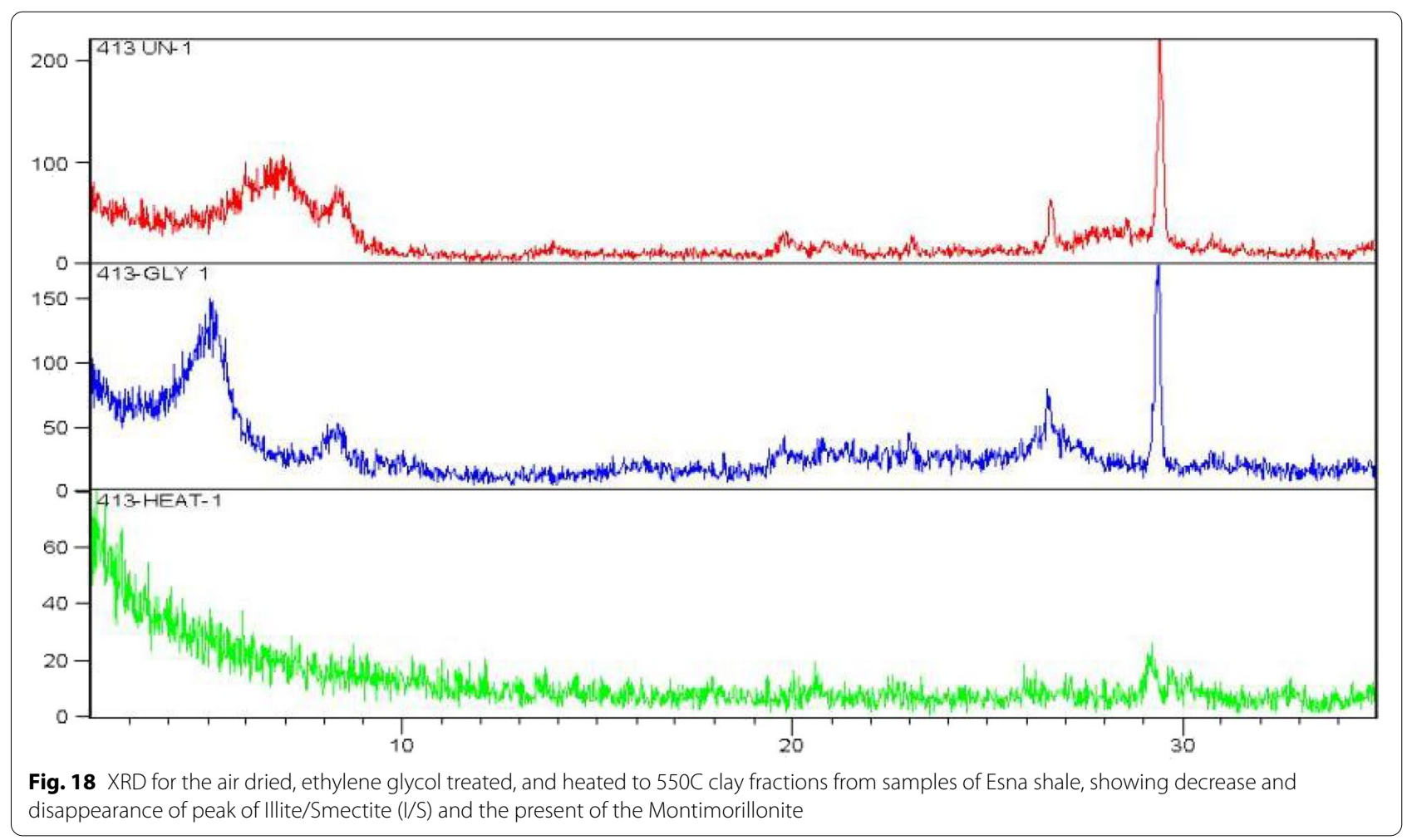




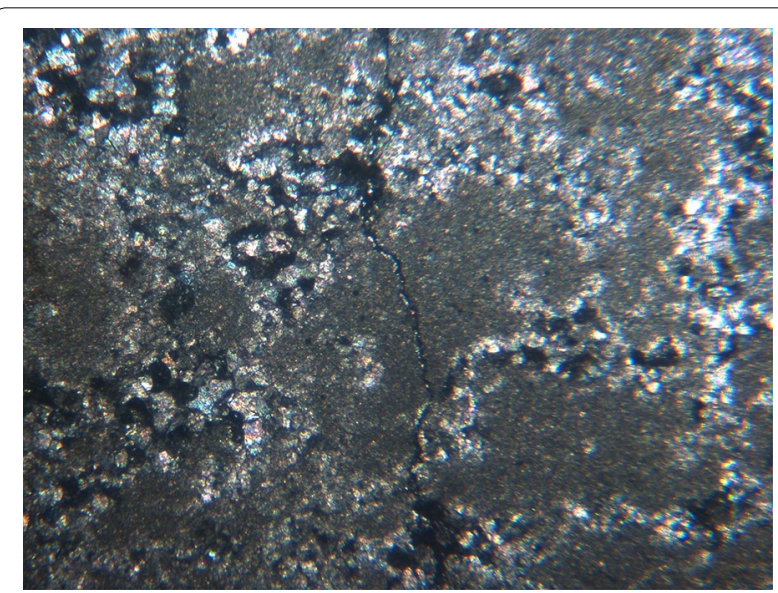

Fig. 19 C.N. Microscopic photograph shows The marl sample from Member I is very fine-grained to fine-grained. Considerable amounts of cavities and microvienlets filling by recrystallized dolomite are observed in the micritic calcite matrix. The rock is very to fine-grained and composed mainly of calcite and dolomite as the essential components associated with minor amount of clay minerals and rare amounts of microcrystalline quartz, iron oxides and opaques. Calcite represents the matrix of the rock and occurs as very fine-grained (micrite), anhedral to subhedral interlocked crystals. Dolomite occurs as very fine to fine-grained, euhedral to subhedral crystals and filling microvienlets and cavities. Quartz is detected as very fine-grained crystals scattered in the matrix. Some pores of irregular shapes and various sizes are observed scattered in the rock. Some parts of the sample are stained by iron oxides

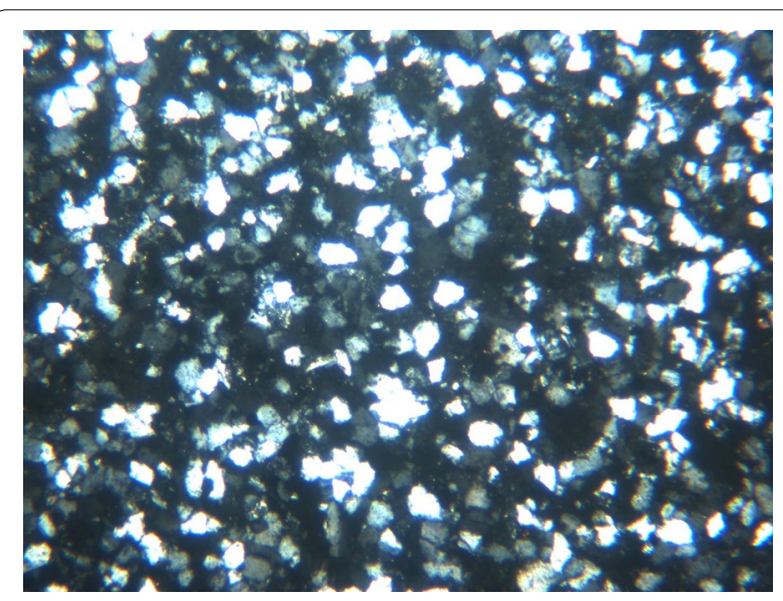

Fig. 20 C.N. Microscopic photograph shows the Esna shale sample is very fine to fine-grained (mainly sand size), well sorted that is cemented by minor amounts of iron oxides, clay minerals and carbonates. The sample is porous where pore spaces of different sizes are observed. The rock is composed mainly of quartz and feldspar grains cemented by minor amounts of iron oxides, clay minerals and calcite. Rare amounts of muscovite, biotite, hornblende and opaque minerals are observed in the sample. Quartz occurs as very fine to fine grains of subrounded to angular shape. Feldspars occur as fine grains that are observed in different parts of the sample. Opaque minerals occur as very fine to fine-grained crystals, scattered in the sample. Some parts of the sample are stained by traces of iron oxides
Table 6 The geotechnical properties of the intact marl limestone samples of the lower Thebes Formations where the entrance of Horemheb tomb (KV57) is excavated

\begin{tabular}{lllll}
\hline No & PI (MPa) & oc (MPa) & Vs (km/s) & RN \\
\hline 1 & 0.3 & 8.7 & 0.9 & 20 \\
2 & 0.4 & 8.9 & 0.7 & 21 \\
3 & 0.4 & 8.0 & 0.9 & 22 \\
4 & 0.4 & 9.0 & 0.9 & 19 \\
5 & 0.5 & 8.9 & 0.8 & 20 \\
6 & 0.4 & 9.3 & 0.9 & 19 \\
7 & 0.3 & 8.4 & 0.8 & 20 \\
\hline
\end{tabular}

LL $75-80 \%$, PI 422-432\%, slurry\% 70-80. Esna rock has weak elastic parameters, in which the modulus of elasticity is constant $\mathrm{E}=1500-2000 \mathrm{kN} / \mathrm{m}^{2}$ and Poisson's ratio $\mathrm{v}=0.23$ (minimum) to 0.4 (maximum). As for the parameters of the shear resistance of this also very poor, the cohesion of the grain particles is $\mathrm{c}=30 \mathrm{kN} / \mathrm{m}^{2}$, the angle of internal friction $\phi=25$. Free swelling\% 100-180, and the swelling pressure is $710-742 \mathrm{kPa}$. The activity percentage is 1.5-2. The results are summarized in Table 7.

Long-term swelling test on samples of Esna shale showed tremendous water absorption and swelling capacity. The size of the swelling ranges from 50 to $80 \%$. Most of them happen within the first hour. The swelling pressure exceeds $5 \mathrm{MPa}$ and $13 \mathrm{MPa}$ with deformations of 1.5 and $3.3 \%$, respectively. Table 8 Summarizes the geotechnical characteristics of intact Marl limestone samples with depth and shear parameters of the rock mass discontinuities where the tomb of Horemheb (KV57) was excavated.

According to ASTM C568/C568M-15, the physical properties of marley limestone and shale are low, since water absorption by weight/maximum should be in the range of $3 \%$ for low density limestone to $12 \%$ for high density limestone.

According to ASTM C 170, C 880 and C 99 test methods and specifications of ASTM C568/C568M-15, the physical and mechanical properties of Marley limestone and shale are low, due to standard requirements for uniaxial compressive strength (c) the size of limestone should be between $12 \mathrm{Mb}$ Pa for low density limestone to $55 \mathrm{MPa}$ for high density limestone.

\section{Analysis of rock mass strength using RocLab Program}

RocLab is a software program to determine rock mass strength parameters, based on the latest version of the Generalized Hoek-Brown Failure Standard, [25].

Hoek-Brown classification: intact limestone uniaxial compressive strength $(\sigma \mathrm{ci})=8 \mathrm{MPa}, \mathrm{GSI}=50$, Slim modulus $($ mile $)=9$, disturbance factor $(D)=0$, intact 
Table 7 The geotechnical properties of the Esna shale samples where the Horemheb tomb (KV57) is excavated

\begin{tabular}{|c|c|c|c|c|c|c|c|c|c|c|c|}
\hline Sample No & $\begin{array}{l}\text { Natural water } \\
\text { content } \%\end{array}$ & $\begin{array}{l}\mathrm{yb} \\
\mathrm{N} / \mathrm{m}^{3}\end{array}$ & $\begin{array}{l}\gamma d \\
N / m^{3}\end{array}$ & $\begin{array}{l}\text { qu } \\
\mathrm{MPa}\end{array}$ & OMC \% & LL (\%) & $\begin{array}{l}\mathrm{PI} \\
(\%)\end{array}$ & $\begin{array}{l}\text { Free } \\
\text { Swelling } \\
(\%)\end{array}$ & Clay (\%) & $\begin{array}{l}\text { Swelling } \\
\text { pressure } \\
(\mathrm{kPa})\end{array}$ & $\begin{array}{l}\text { Activity } \\
\text { (\%) }\end{array}$ \\
\hline 1 & 8.1 & 18 & 17 & 0.48 & 14 & 75 & 422 & 100 & 70 & 710 & 1.5 \\
\hline 2 & 8.9 & 20 & 17 & 0.53 & 15.6 & 79 & 424 & 160 & 77 & 732 & 1.7 \\
\hline 3 & 9.8 & 20 & 18 & 0.65 & 16.2 & 81 & 432 & 180 & 80 & 742 & 2 \\
\hline
\end{tabular}

Table 8 a The geotechnical properties of the intact limestone samples with depth and b. shear parameters of the discontinuities where the Horemheb tomb (KV57) is excavated

\begin{tabular}{llll}
\hline Depth & Weathering Grade & UCS (MPa) & $E\left(\mathbf{k N} / \mathbf{m}^{\mathbf{2}}\right)$ \\
\hline $0-1 \mathrm{~m}$ & IV & $3-7$ & 1500 \\
$1-2 \mathrm{~m}$ & III & $7-10$ & 1600 \\
$2-3 \mathrm{~m}$ & IIIII & $10-11$ & 1900 \\
$3-4 \mathrm{~m}$ & III & $11-12$ & 2000 \\
\hline Type & Peak Friction & Residual Friction & In-Situ \\
\hline Joints & $35^{\circ}$ & $35^{\circ}$ & $\mathrm{JRC}$ \\
Joints & $35^{\circ}$ & $30^{\circ}$ & $(\mathrm{L}=1 \mathrm{~m})=3-4$ \\
Joints & $30^{\circ}$ & $35^{\circ}$ & $\mathrm{C}=35 \mathrm{kPa}$ \\
\hline
\end{tabular}

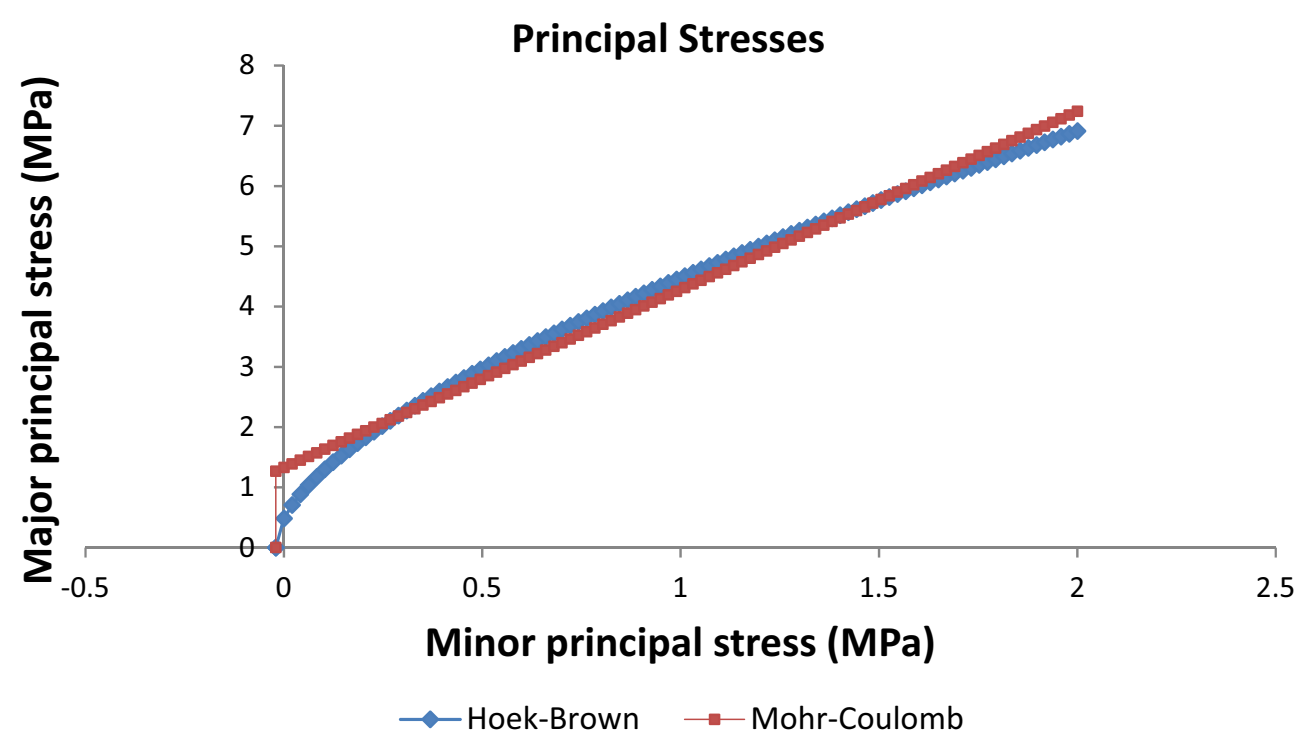

Fig. 21 Major and minor principal stress curve of marl limestone (KV57) using the RocLab program 


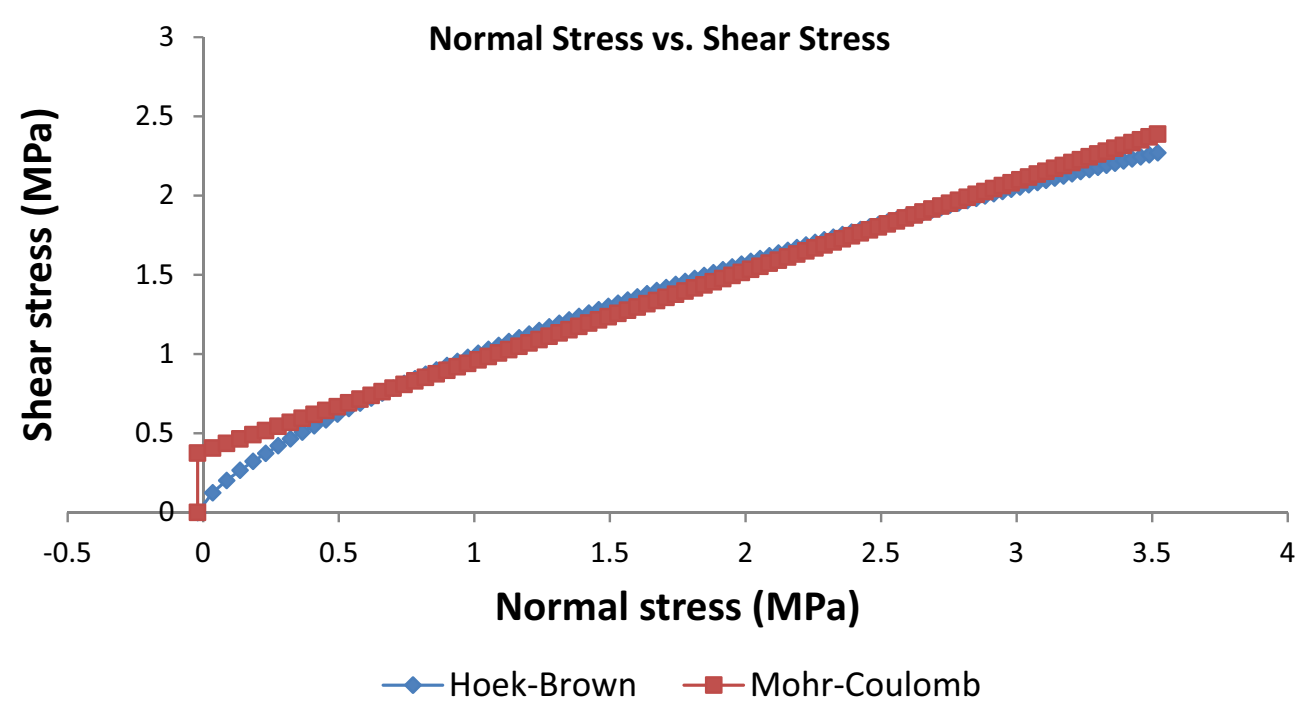

Fig. 22 Shear stress-Normal stress curve of Marl limestone (KV57), using the RocLab program

Table 9 Hoek Brown classification, Hoek Brown Criterion, Failure Envelope Range, Mohr- Coulomb Fit and Rock mass parameters for the marl limestone member 1 where the Horemheb tomb (KV57) is excavated, using the RocLab program

\begin{tabular}{lll}
\hline Hoek brown classification & & \\
$\sigma c i$ & 8 & $\mathrm{MPa}$ \\
$\mathrm{GSI}$ & 50 & \\
$\mathrm{mi}$ & 9 & \\
$\mathrm{D}$ & 0 & \\
$\mathrm{Ei}$ & 12,000 & \\
Hoek brown criterion & & \\
$\mathrm{mb}$ & 1.5091 & \\
$\mathrm{~S}$ & 0.003866 & \\
$\mathrm{a}$ & 0.505734 & $\mathrm{MPa}$ \\
Failure envelope range & & \\
Application & $\mathrm{General}$ & $\mathrm{MPa}$ \\
$\sigma_{3}$ max & 2 & $\mathrm{degrees}$ \\
Mohr-Coulomb fit & & \\
$\mathrm{C}$ & 0.385958 & $\mathrm{MPa}$ \\
phi & 29.6249 & $\mathrm{MPa}$ \\
Rock mass parameters & & $\mathrm{MPa}$ \\
$\sigma_{\mathrm{t}}$ & -0.02049 & $\mathrm{MPa}$ \\
$\sigma_{\mathrm{c}}$ & 0.481818 & \\
$\sigma_{\mathrm{cm}}$ & 1.32695 & \\
$\mathrm{E}_{\mathrm{rm}}$ & 3686.23 & \\
\hline
\end{tabular}

rock deformation factor $\mathrm{Ei}=12,000 \mathrm{MPa}$, coefficient ratio $(M R)=500$.

Generalized Hoek-Brown criterion failure criterion $(\mathrm{mb})=1.509 . \mathrm{s}=0.003866 . \mathrm{a}=0.50573$, where $(\mathrm{s})$ and (a) are rock mass constants, calculated from the geological strength index (GSI) and disturbance factor (D).

Mohr-Coulomb Fit: cohesion $(\mathrm{c})=0.3859 \mathrm{MPa}$, angle of friction $\phi=29.620$.

Parameters of rock mass: tensile strength of intact rocks $\sigma \mathrm{t}=-0.016 \mathrm{MPa}$, uniaxial compressive strength $800 \mathrm{kPa}$, as shown in Figs. 21 and 22. Table 9 summarizes the Hoek Brown, Hoek Brown Criterion, Failure Envelope Range, and Mohr-Coulomb Fit classification and rock mass parameters of the Marl 1 limestone member where the entrance to Horemheb's tomb (KV57) was excavated using RocLab software.

\section{Results of the 3D numerical analysis and geotechnical modeling}

In this study, PLAXIS 3D, [26] was performed to determine the behavior of rock formations under severe geostatic stresses. Plaxis is a commercially available software that uses the FEM Finite Element method. Plaxis uses different soil/rock models to define soil/ rock behavior such as the Mohr-Coulomb model, the hard soil model, the loose soil model, the soft soil creep 


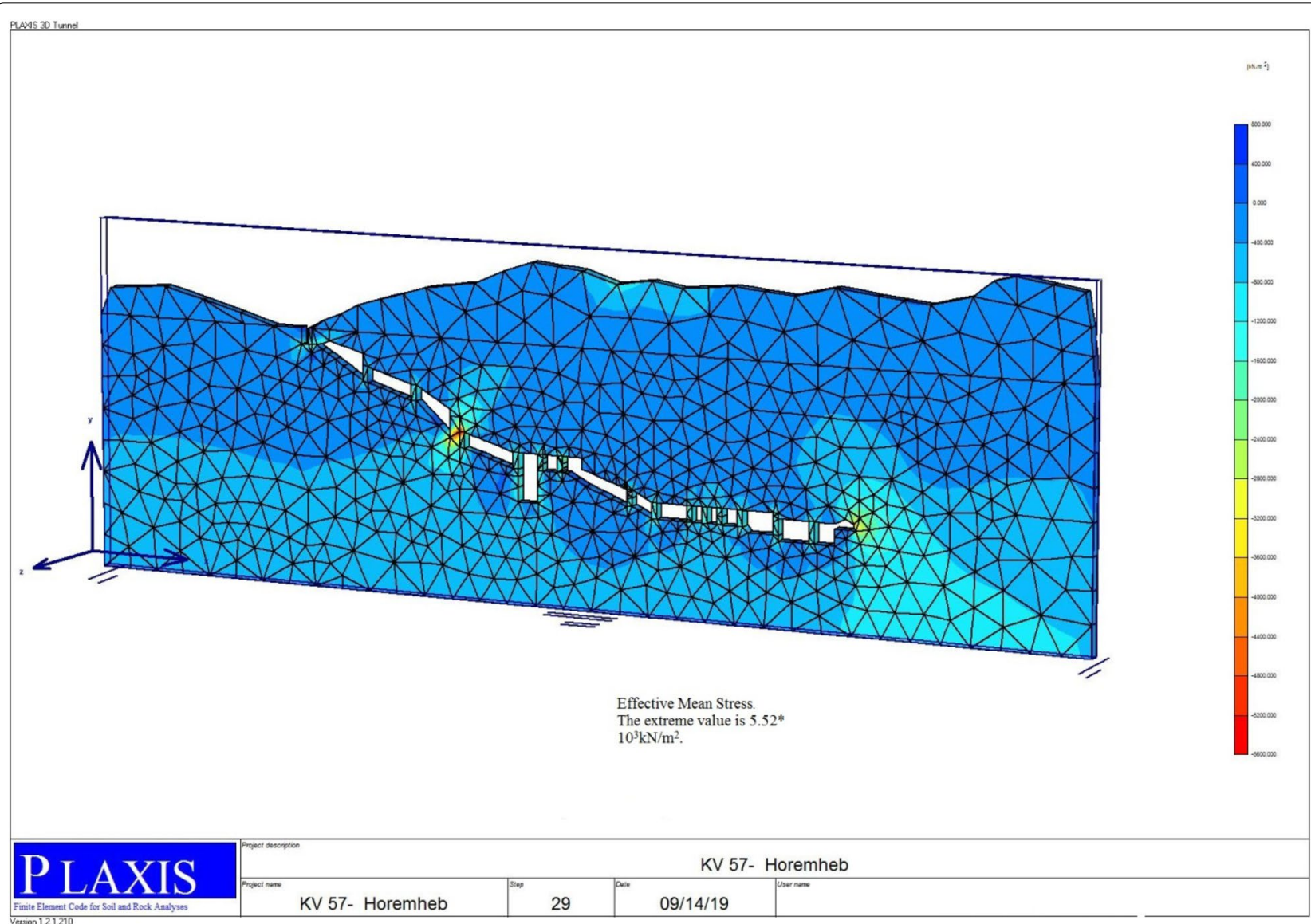

Fig. 23 Effective mean stresses for the supported rock pillars and sidewalls in KV57, the extreme value is $5.52^{*} 103 \mathrm{kN} / \mathrm{m}^{2}$

model, the common rock model, and the modified Cam-Clay model. Soil hardening model was chosen for this geotechnical modeling in this study.

Soil hardening model is an advanced model for simulating soil behavior. For the Mohr-Coulomb model, the stress states defined by the angle of friction phi, coherence c, and the expansion angle psi are described. However, soil hardness is more precisely described using three different types of input hardness: E50 three-axis hardness, three-axis European dumping hardness, and Ooed counter-loading hardness. In contrast to the Mohr-Coulomb model, the solidified soil model also explains the dependence of stiffness parameters on stress. This means that all stiffness increases with pressure. Hence, the stiffness of the three inputs relates to the reference pressure, and is usually taken as $100 \mathrm{kPa}$ (1 bar).

Besides the above model parameters, initial soil conditions, such as pre-consolidation, play an essential role in most soil deformation problems. This can be taken into account when generating the initial pressure.

Low strength rock formations where KV57 has been critically excavated in hazardous safety conditions under constant loading and earthquake conditions. PLAXIS 3D was used for 3D numerical analysis of central main chambers with damage to structural support rock pillars. Vertical cracks due to overload and force slope are evident.

The goal of the 3D test is to assess the pressure condition in the columns while observing the $3 \mathrm{D}$ geometry. 


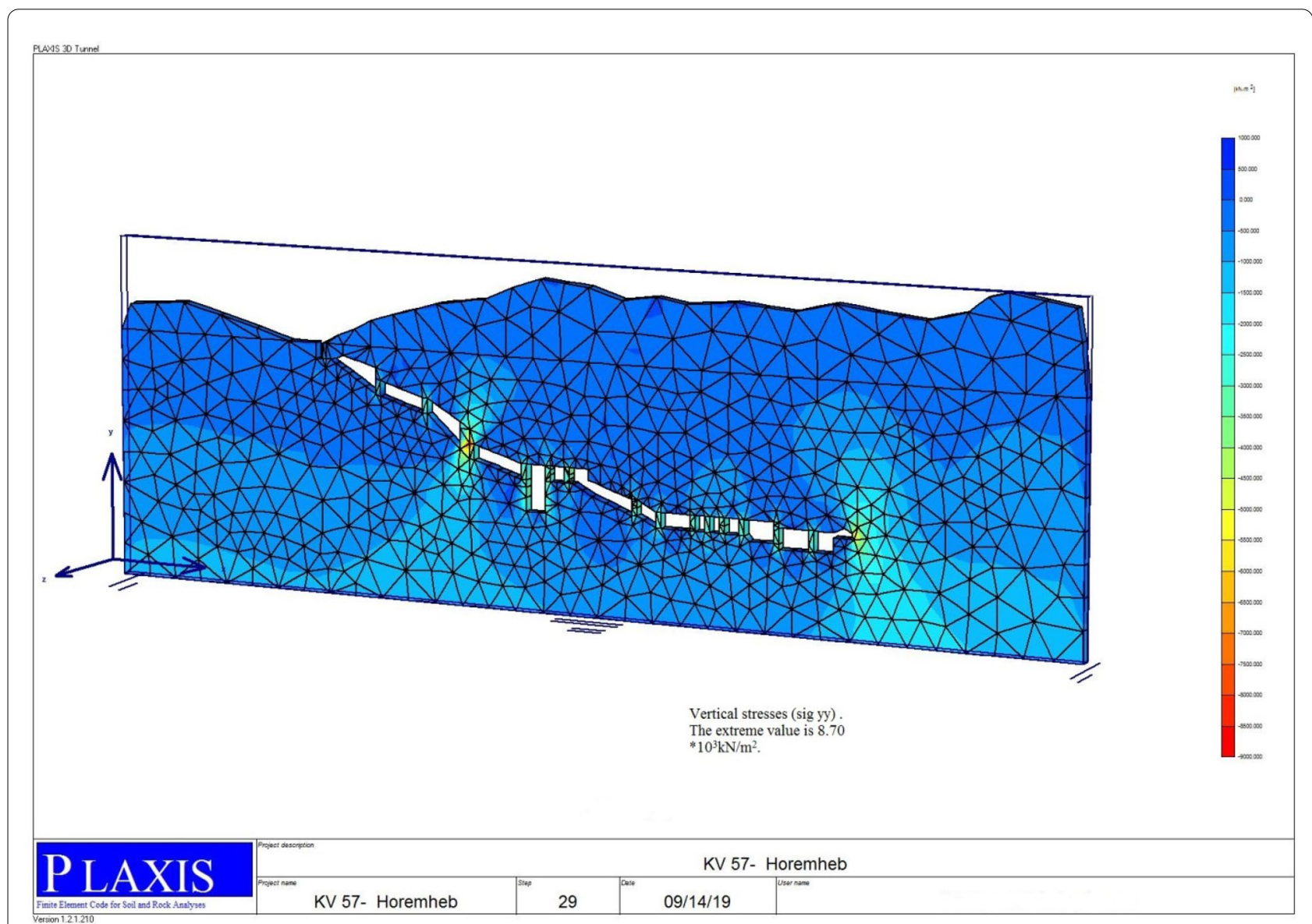

Fig. 24 Vertical stresses (sig yy) for the supported rock pillars and sidewalls in KV57, the extreme value is $8.70^{*} 103 \mathrm{kN} / \mathrm{m}^{2}$

The issue of 3D influences on basic design methodology is considered in the following areas. The different iterations displayed were redirected with the PLAXIS 3D (PLAXIS 3D) code.

The results of the 3D static analysis are represented in the Figs. 23, 24, 25, 26, 27, 28, 29, 30, 31 show that the rock columnsor pillars in the main rooms are subjected to relatively high pressure pressures. The peak pressure of the calculated main effective pressure of the rock pillars and the supporting side walls is $5.52 \times 10^{3} \mathrm{kN} /$ $\mathrm{m}^{2}$ as shown in Fig. 23. The maximum effective vertical pressure calculated on the rock pillars and the supporting side walls is $8.7 \times 10^{3} \mathrm{kN} / \mathrm{m}^{2}$ as shown in Fig. 24.The effective horizontal average pressures $4.94 \times 10^{3} \mathrm{kN} /$ $\mathrm{m}^{2}$ as shown in Fig. 25. Figure 26 represents the plastic points (Mohr-Coulomb and Tension Cut-off points) for the roof, reinforced rock pillars and side walls of KV57. The total displacement of the roof and columns is $30.92 \mathrm{~mm}$, as shown in Fig. 27. The vertical displacement is $30.76 \mathrm{~mm}$ as shown in Fig. 28. The horizontal displacement is $15.52 \mathrm{~mm}$ as shown in Fig. 29. The total additional displacement is $1.07 \mathrm{~mm}$ as shown in 


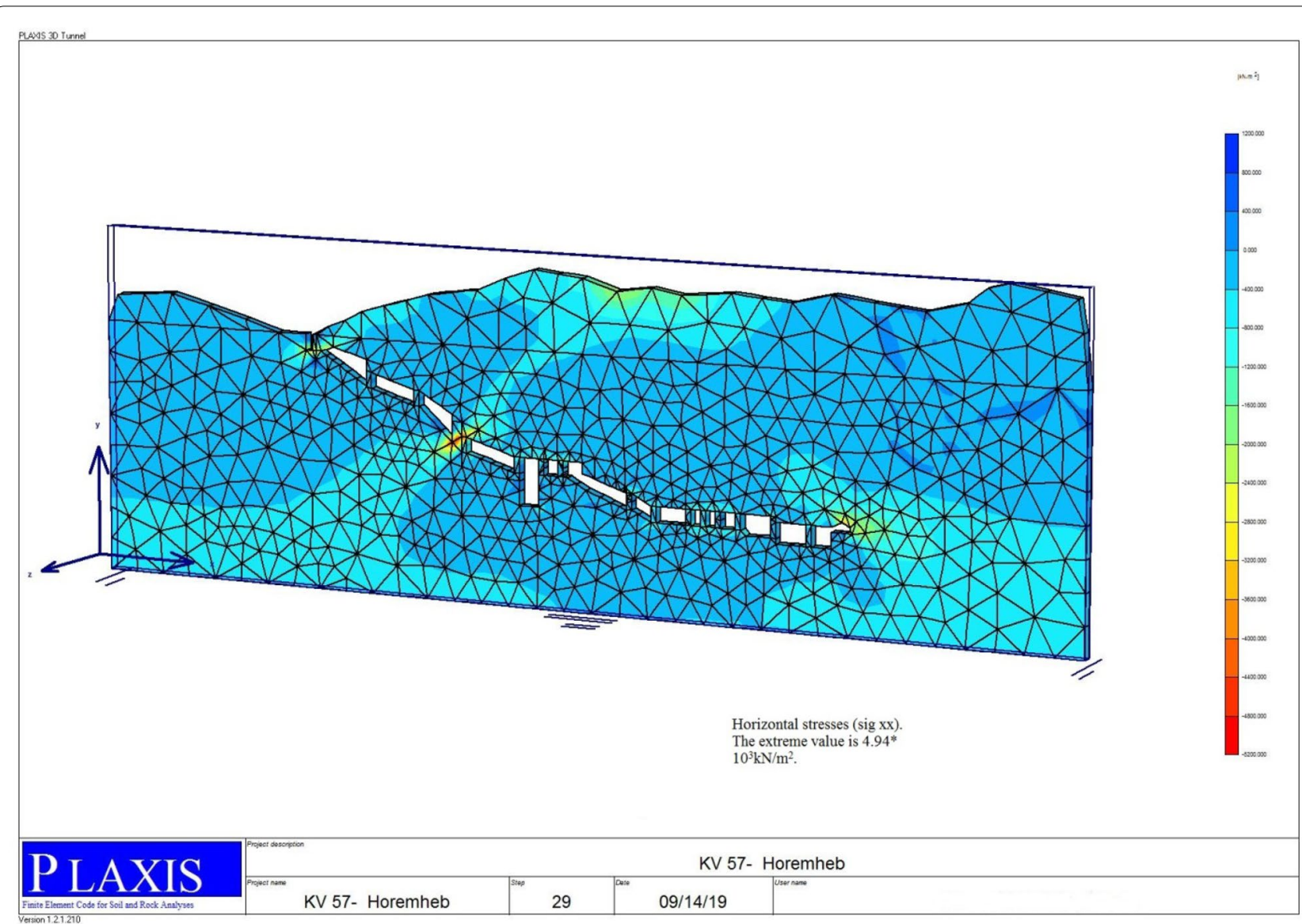

Fig. 25 Horizontal stresses (sig $x x$ ) for the supported rock pillars and sidewalls in $\mathrm{KV} 57$, the extreme value is $4.94 * 103 \mathrm{kN} / \mathrm{m}^{2}$

Fig. 30 and the volumetric pressure is $1.45 \%$ as shown in Fig. 31.

The results showed that the values of pressure distribution and displacement on structural rock surfaces and columns did not increase due to the drilling process extended behind the main hall, and this may be due to the low level of the ceiling for these small rooms. The numerical results indicated that failure could be further affected by orientation of vertical joint groups rather than bed planes.

A numerical analysis reveals that the roof of the grave that has suffered peeling is the compacted surface. Given that the peeling is the result of a combination of moisture fluctuations and compressive pressure, the study concluded that moisture fluctuation needs to be minimized by preventing the active circulation of air through the tomb.

Shaft axial pressure curves versus displacement curves provide insight into the mechanism of shaft failure associated with increased axial loads. It can be seen that for plumes with $\mathrm{W} / \mathrm{H}=1 / 3 \leq 0.5$, the columns generally exhibit linear elastic behavior reaching peak strength and then brittle failure followed by an approximate post-peak behavior of plastic.

The results indicate general agreement with the empirical relationship between column width and aspect ratio. On the other hand, there is a significant decrease in the column strength for the ratios $\mathrm{W} / \mathrm{H}<0.5$. In these cases and where the stability of the shaft is controlled by unfavorable defects. 


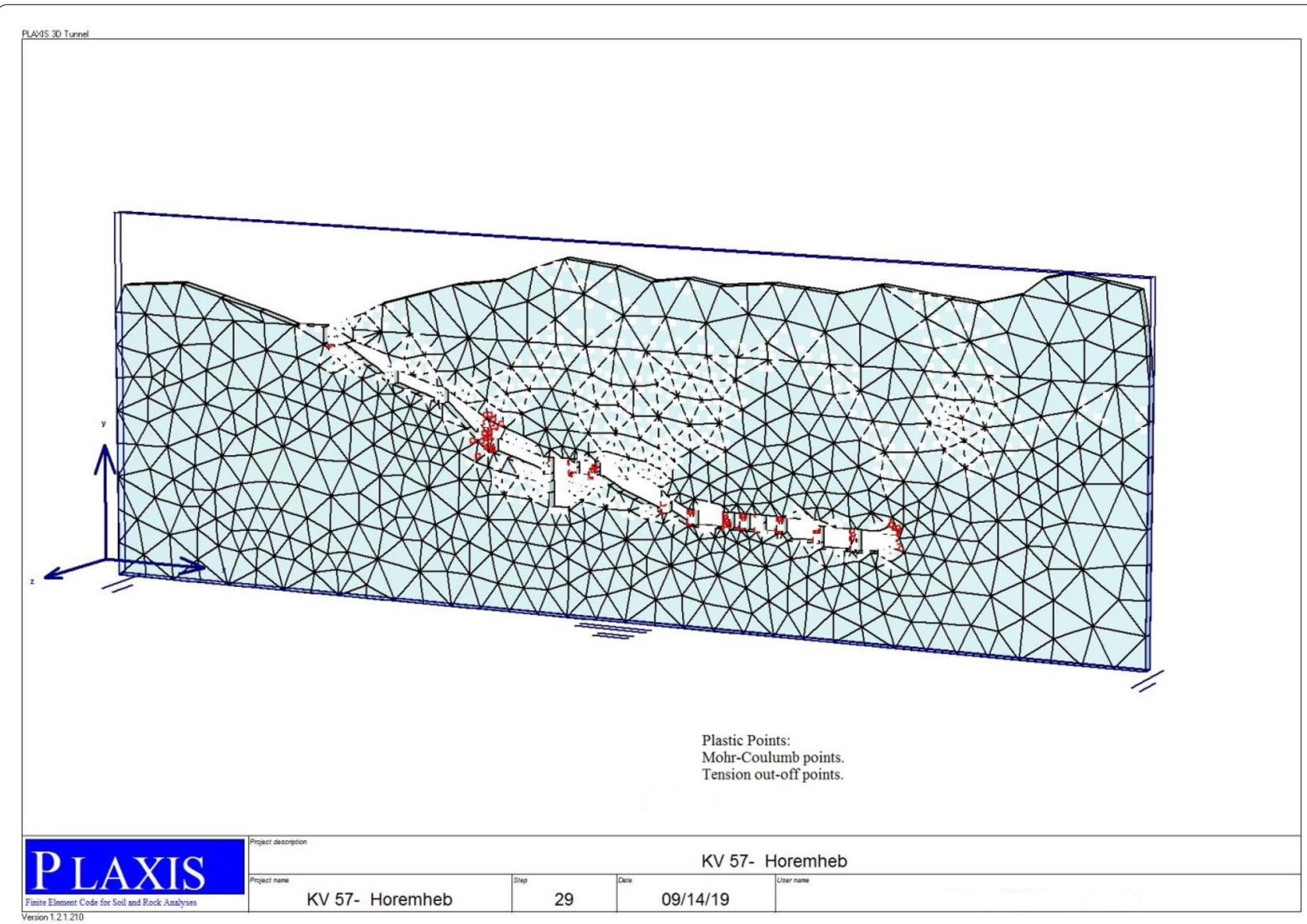

Fig. 26 Plastic points (Mohr-Coulomb and Tension cut-off points) for the supported rock pillars and sidewalls in KV57

\section{Evaluate the safety factor and stress state in the structural support pillars}

$$
\text { Factor of Safety }=\text { FoS }=\frac{\text { Strength of Material }}{\text { Max Computed Stress }}=\frac{\text { Failure Stress }}{\text { Actual Stress }}
$$

The designer defines failure; component/structure doesn't meet performance criteria;

e.g. excessive deformation, fracture, etc.
FoS $>1$ is The design criteria the engineering component/structure must achieve.
In general, Use higher FoS for brittle materials (to avoid catastrophic failure). Use lower FoS when using materials 


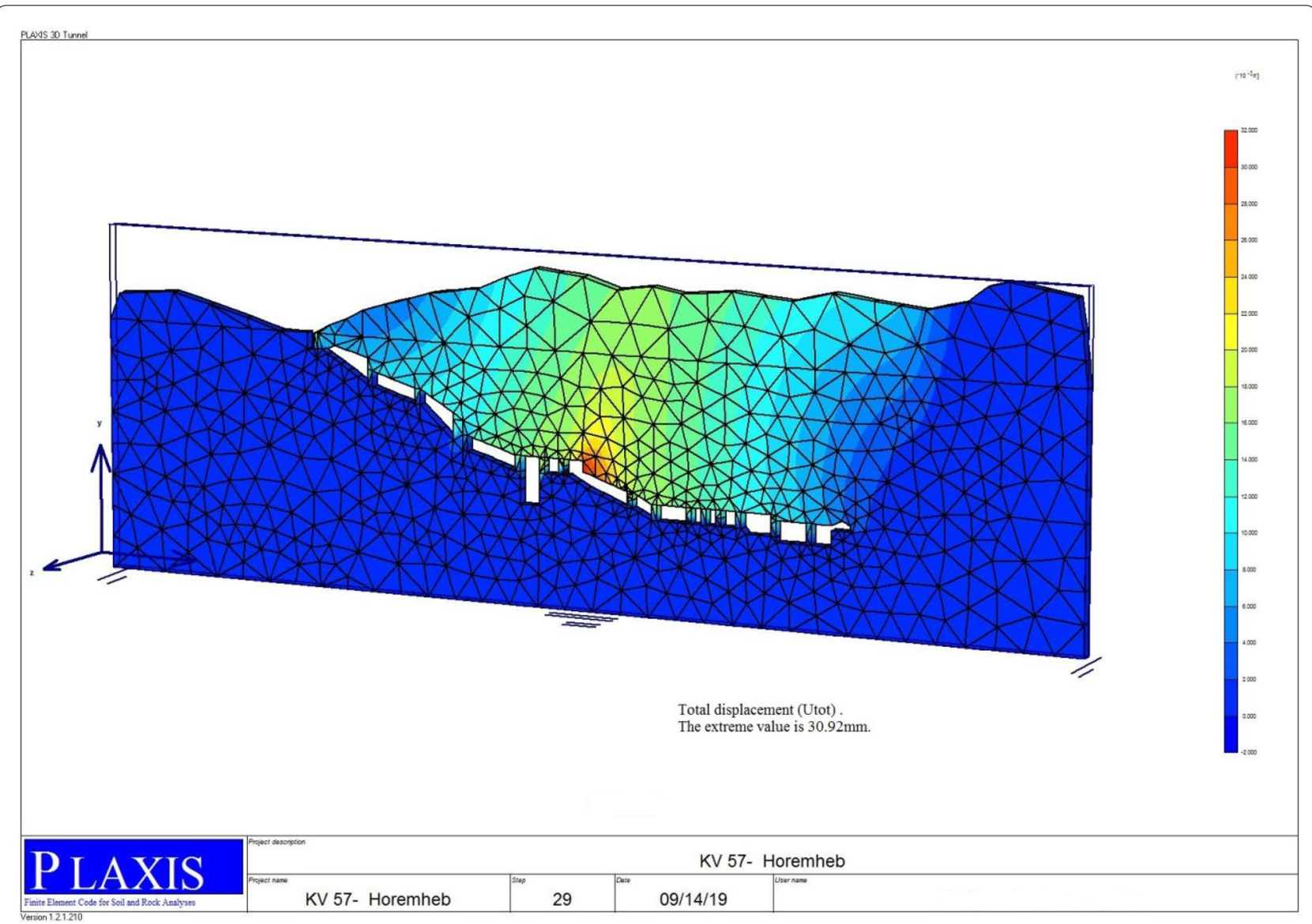

Fig. 27 Total displacement (Utot) for the supported rock pillars and sidewalls in KV57, the extreme value is $30.92 \mathrm{~mm}$

for which the material properties are very well known. Use higher FoS for uncertain environments/stresses.

Typical Values for the Factor of Safety (FoS) of the buildings is $\geq 2$. Bolts $\geq 8.5$.

It is demonstrated that induced stresses of significant magnitude and ambiguous distribution are to be expected in the supporting pillars. Multiple openings and excavations designed on the basis of the average stress in the pillar $\sigma \mathrm{v}^{-}$given by the tributary area theory, as explained in Eq. (1).

$$
\sigma v-=\frac{A t}{A P} \sigma v
$$

where,

- $A_{t}$ is the area supported by the pillar 


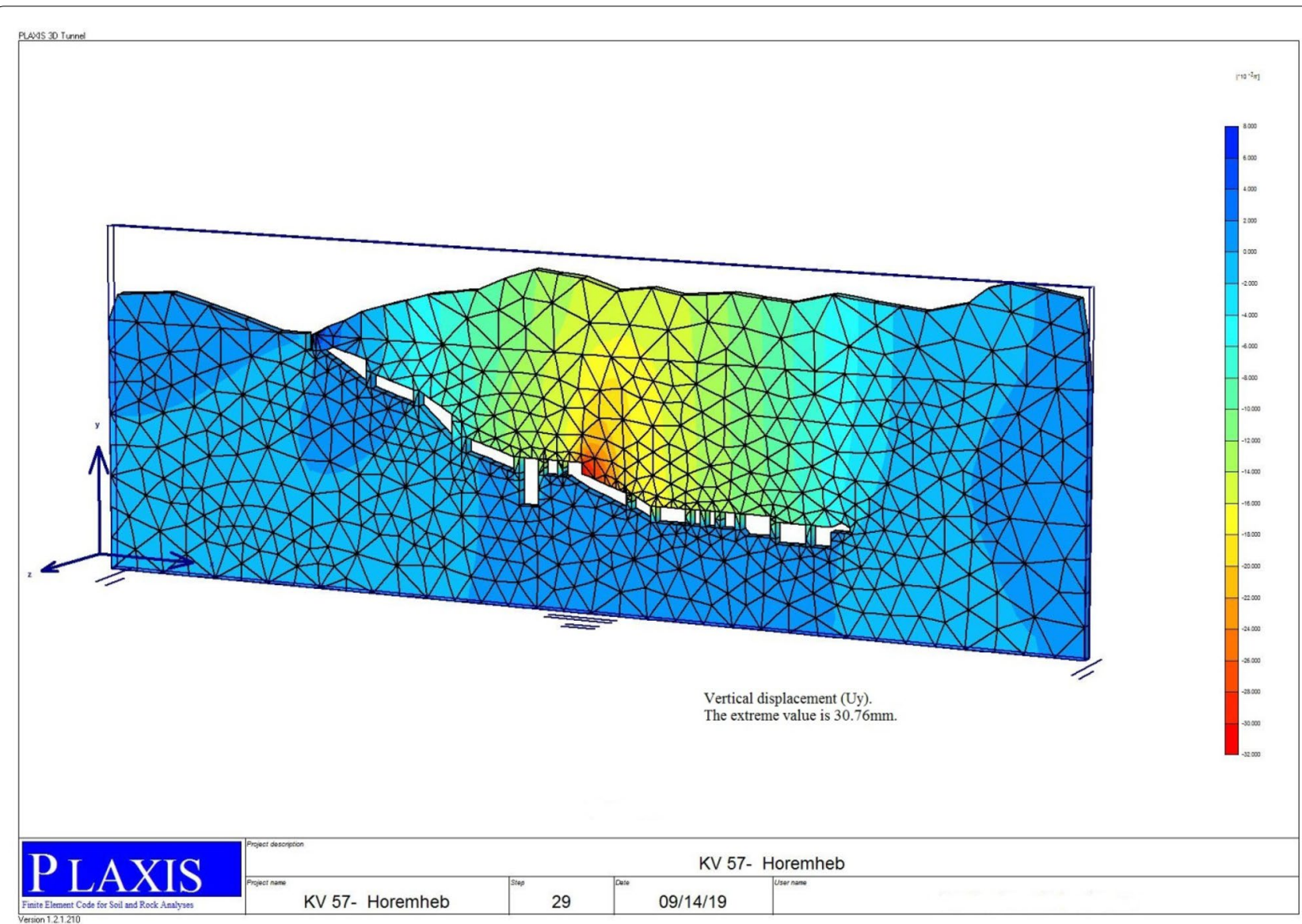

Fig. 28 Vertical displacement (Uy) for the supported rock pillars and sidewalls in KV57, the extreme value is $30.76 \mathrm{~mm}$

- $\mathrm{A}_{\mathrm{p}}$ is the area of the pillar

- $\sigma_{v}$ is the vertical stress at the level of the roof of the excavation (catacombs)

To evaluate the degree of safety of a pillar, we must be compare the above average pillar stress $\sigma_{v}$ with the pillar strength $\sigma_{\mathrm{p}}$. The latter is not simply the unconfined compressive strength of the material comprising the pillar $\mathrm{q}_{\mathrm{u}}$, because shape and size effects introduce significant modifications from the breaking strength of unconfined compressive cylinders.

The strength in compression for rectangular pillars of square cross section can be estimated from the Eq. (2). 


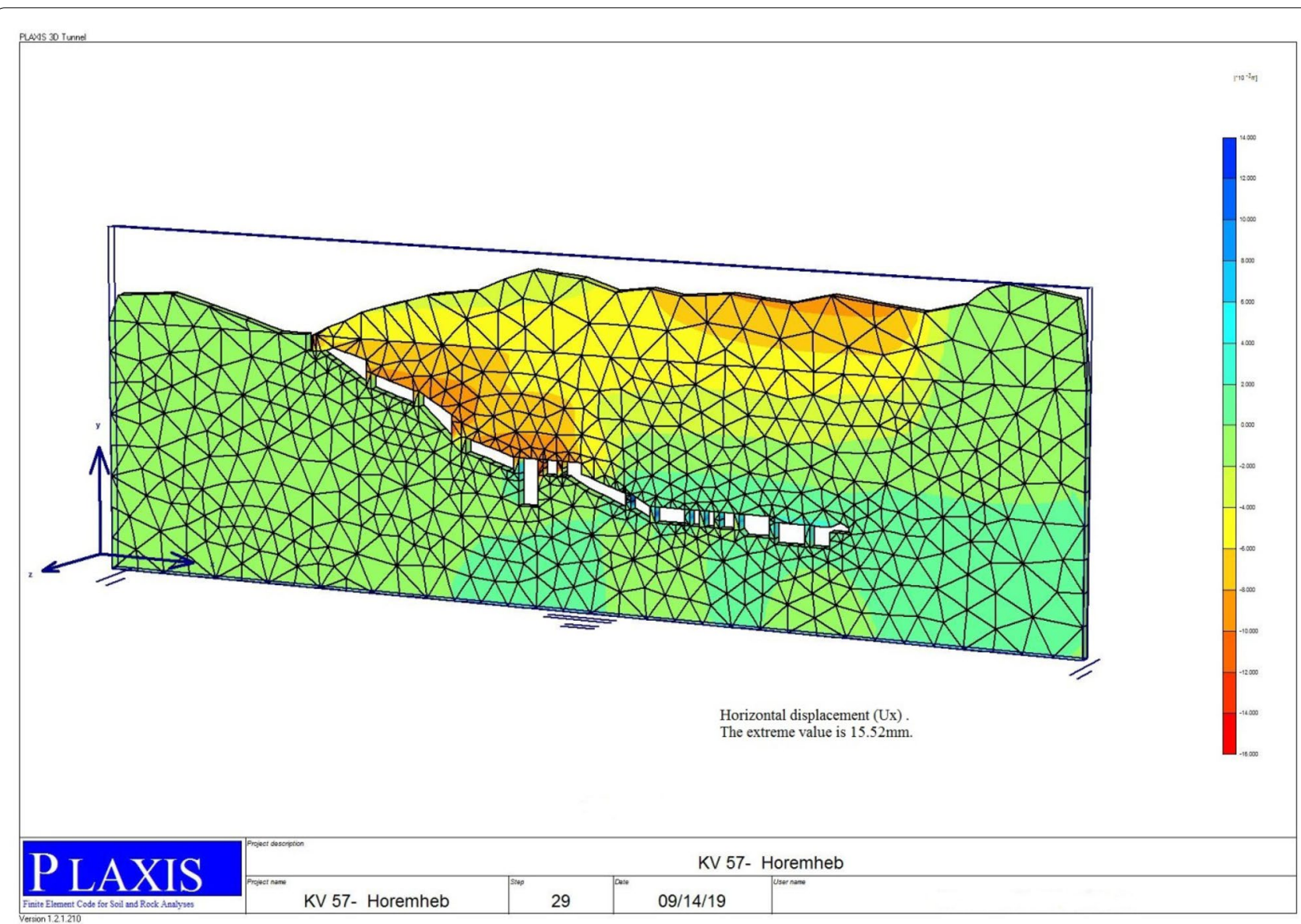

Fig. 29 Horizontal displacement (Ux) for the supported rock pillars and sidewalls in KV57, the extreme value is $15.52 \mathrm{~mm}$

$$
\sigma_{\mathrm{p}}=\left\{0.875+0.250 \frac{W}{H}\right\}\left\{\frac{h}{h c r i}\right\}^{0.5}\left(\mathrm{q}_{\mathrm{u}}\right)
$$

where,

- $\sigma_{\mathrm{p}}$ is the strength of the pillar,

- W and $\mathrm{H}$ are the width and height of the pillar respectively,
- $\mathrm{q}_{\mathrm{u}}$ is the UCS strength of the pillar material on cylinders with height (h) equal to twice the diameter and.

- $\mathrm{h}_{\text {crit }}$ is the minimum height of the cubical specimen of pillar material such that an increase in the specimen dimension will produce no further reduction in strength. 


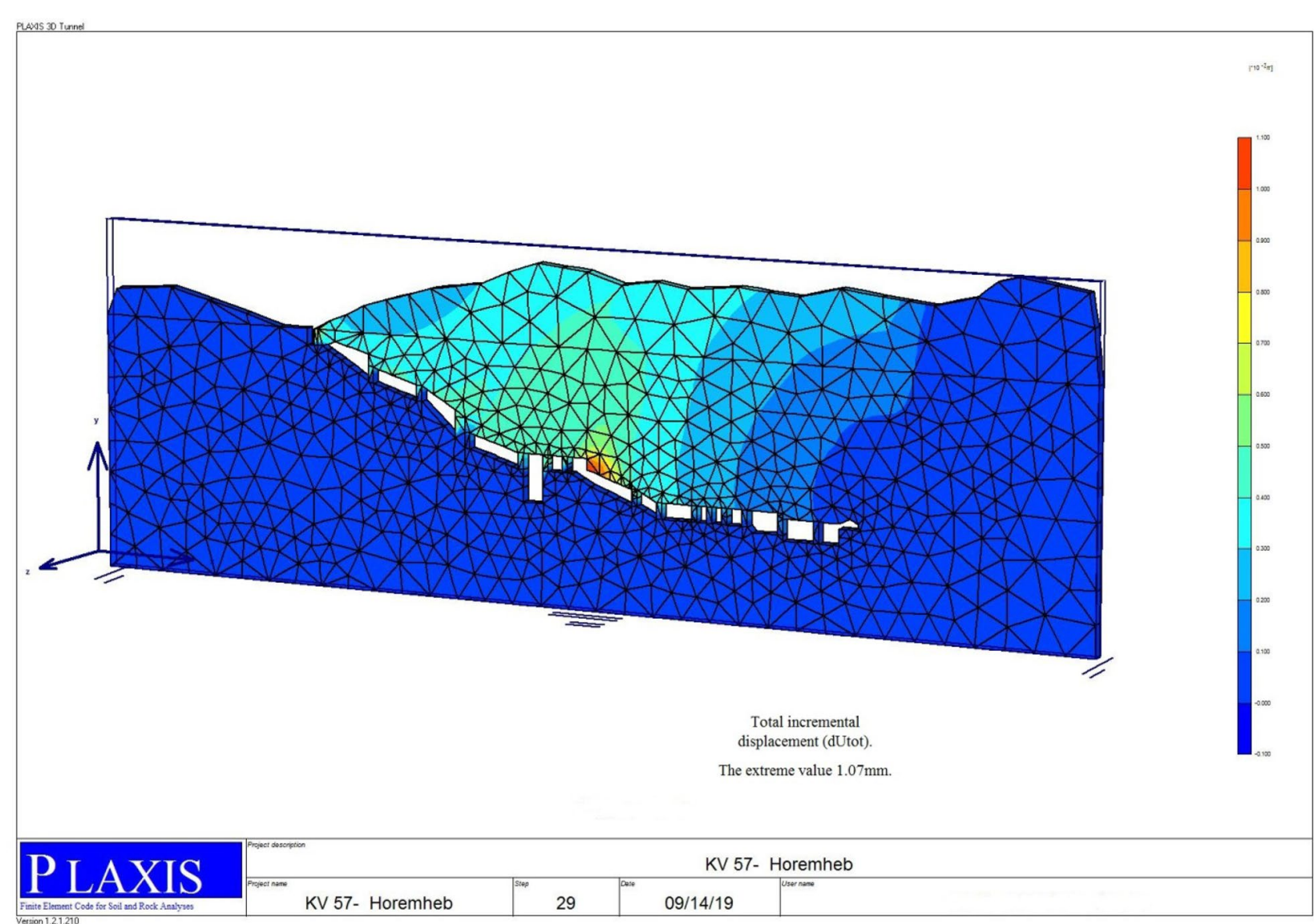

Fig. 30 Total incremental displacement (dUtot) for the supported rock pillars and sidewalls in KV57.The extreme value $1.07 \mathrm{~mm}$

For the pillars, see Fig. 24, $\sigma_{v}=8.7 \mathrm{MPa}, \mathrm{A}_{\mathrm{t}}=2 \mathrm{~m}^{2}$ and $\mathrm{A}_{\mathrm{p}}=1 \mathrm{~m}^{2}$ we can derive:

$$
\sigma \mathrm{v}^{-}=\frac{2}{1} x 8.7=17.4 \mathrm{MPa}
$$

The strength of the pillar $\sigma_{\mathrm{p}}$ can be estimated from the equation: For the pillar we have $\mathrm{W}=1 \mathrm{~m}, \mathrm{H}=3 \mathrm{~m}$. If we assume $h_{\text {crit }}=0.2 \mathrm{~m}$ and $\mathrm{h}=1 \mathrm{~m}$ for $\mathrm{q}_{\mathrm{u}}=8 \mathrm{MPa}$, we have $\sigma_{\mathrm{p}}=17 \mathrm{MPa}$.

And the Factor of Safety F. S $=\frac{\sigma p}{\sigma v-}=\frac{17}{17.4}=\mathbf{0 . 9 7}$ which very low and indicate to the dangerous and unsafe situation and losing of the structural function of these load bearing pillars. [23] quote Salamon and Munro,s suggestion of acceptable safety factors $>1.6$. Such values may be adequate for the excavation stability, [27] and [28].

$$
\text { Also overstress state }=\frac{\sigma c}{\sigma v}=\frac{8 \mathrm{MPa}}{8.7 \mathrm{MPa}}=0.9
$$

The tributary theory is based on average pillar stresses and derived stress value is generally close to the averages predicted by PLAXIS 3D.On other hand, the overloading of geostatic loading due to the overburden strata on the supporting rock pillars is obvious and it induced critical vertical cracks in these pillars also some sections have an overriding influence on the pillar stability, 


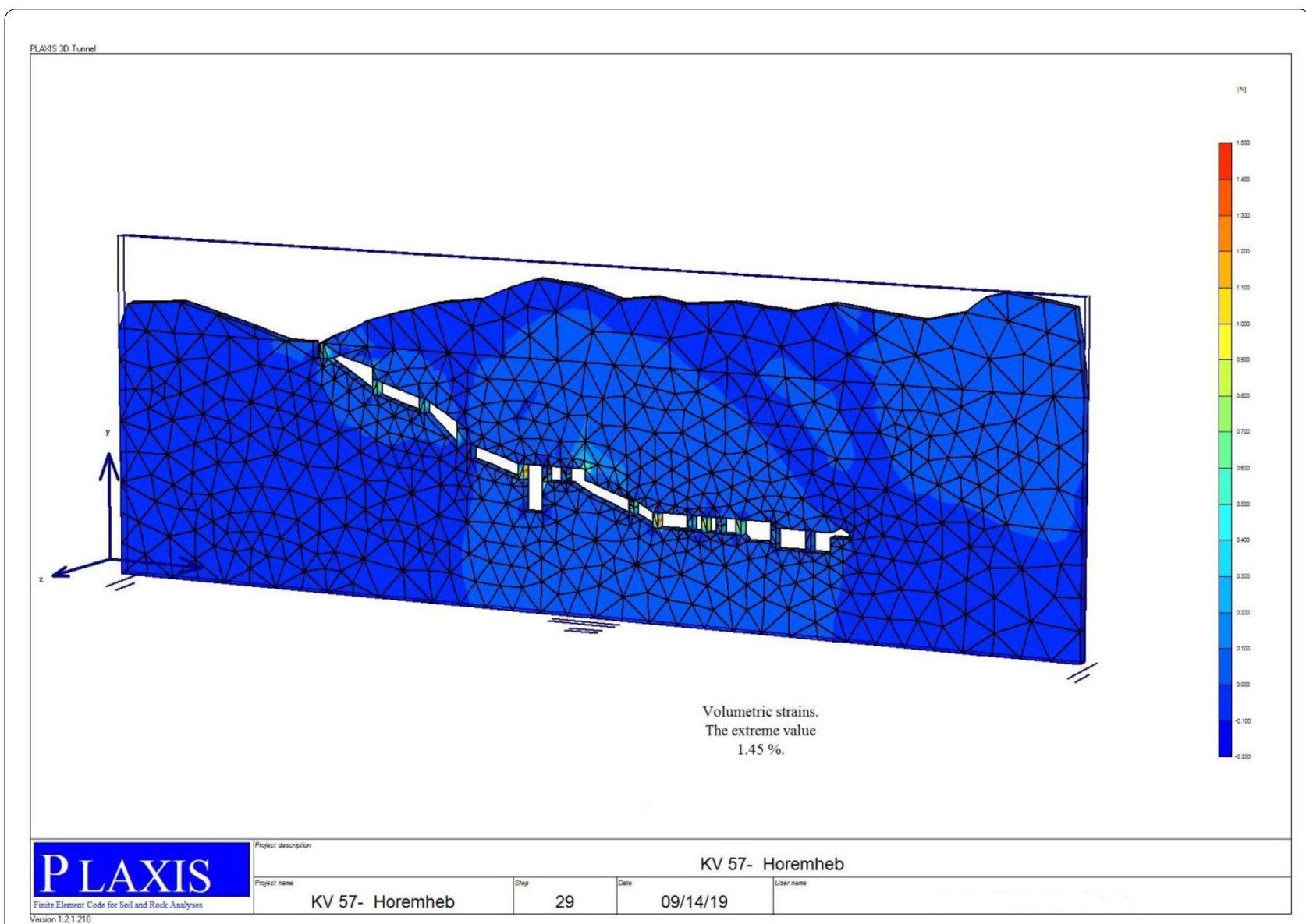

Fig. 31 Volumetric strains for the supported rock pillars and sidewalls in KV57.The extreme value 1.45\%

Eq. 3, particularly in terms of long-term creep effects and associated strength loss or thinning-out of the effective load bearing pillars and section, [29] and [30], as shown in Fig. 32. In the original study of Salamon and Munro this occurred between safety factors of 1.3 to 1.9 with the mean being 1.6. This value was recommended for the design of production pillars in South African bord and pillar workings (Salamon and Munro, 1967), [31].

\section{Design of structural supporting systems}

In order to effectively manage these large deformations, a number of important strengthening design parameters must be established. These include definition of the overexcavation required to provide deformation allowance, as well as determination of support measures. A support system which allows controlled deformations is chosen to limit the required support resistance and to achieve stability. 


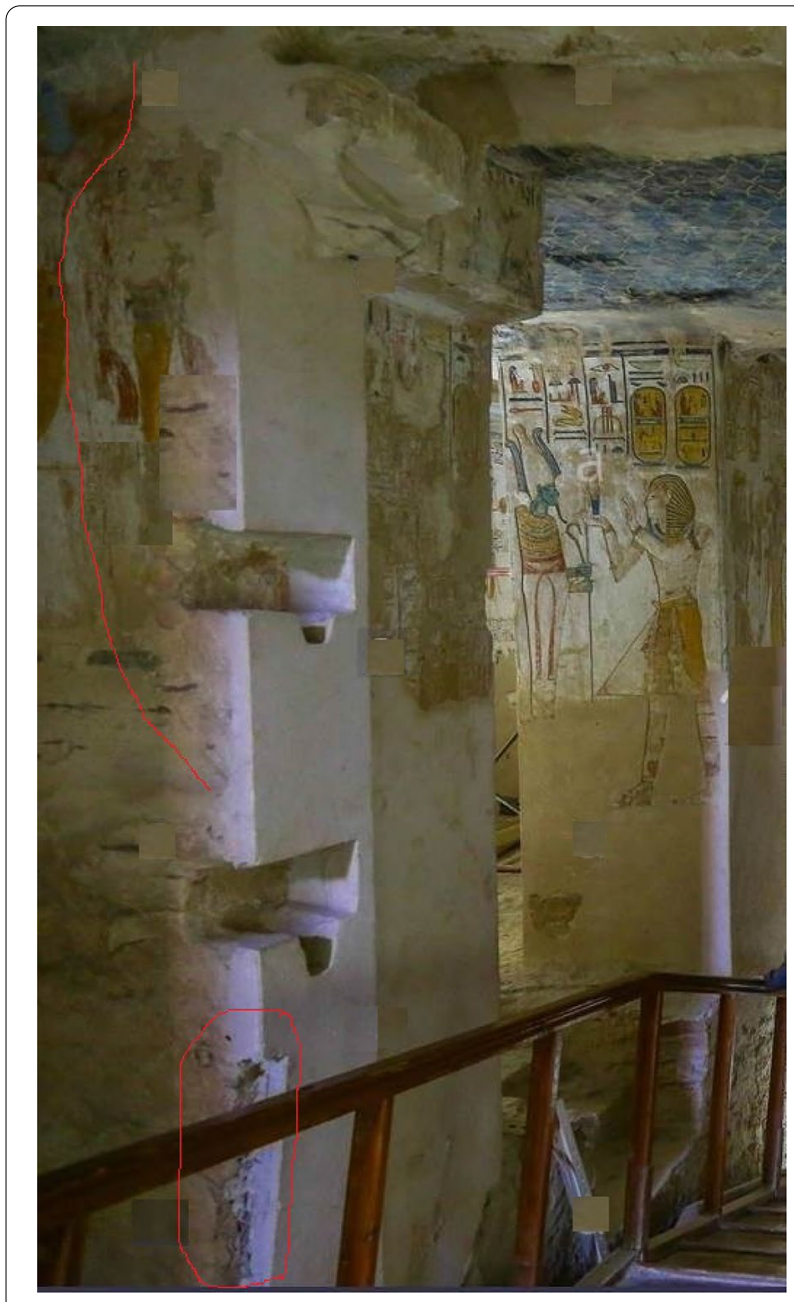

Fig. 32 The overloading of geostatic loading due to the overburden strata on the supporting rock pillars is obvious and it induced critical vertical cracks in these pillars

The Rock Mass Rating classification system relies on a group of six parameters=Intact rock strength, RQD, joint spacing, joint conditions, groundwater and modulus.

The first option is based on the calculation of Bieniawski, s RMR [32] (rock mass classification system), where the strength of sound rock is $8 \mathrm{MPa}$ (at a rate of 1 ), the RQD is 50 (at a rate of 12), and the joint spacing is less than $60 \mathrm{~mm}$ (5), the interruption conditions are 1-5 mm separation with continuous joints (at a rate of 10) and the groundwater conditions are completely dry (at a rate of $14)$, to adjust the direction of the joint is -5 and then RMR from the tomb of the sons of Ramses II (37) which are classified as rocks Poor with high pressure, as shown in Table 10.

\section{Table 10 RMR value for the KV57 is determined as follow}

\begin{tabular}{lll}
\hline Rating & Value & Item \\
\hline 1 & $800 \mathrm{kPa}$ & Uniaxial Compressive Strength \\
12 & 50 & RQD \\
5 & $<0 \mathrm{~mm}$ & Spacing of Discontinuities \\
10 & Separation 1-5 mm & Conditions of Discontinuities \\
& Continuous joints & \\
14 & Completely dry & Ground water \\
-5 & & Adjustment for Joint Orientation \\
37 & & Total \\
Poor rock & & RMR \\
\hline
\end{tabular}

\section{Pillar Stitching}

Pillar stitching with high strength rock bolts provide a significant increase in pillar strength. If a weaker rock layer exists in the pillar, the benefits of pillar stitching were mainly observed as a post-peak behaviour resulting in a more controlled failure, particularly for $\mathrm{W} / \mathrm{H}>0.5$, [33, 34].

According to the calculated RMR value and the guidelines for drilling and supporting 10-m long rock tunnels according to the RMR system (after Bieiniawski 1989, [29]), as summarized in Table 11, the complete column support system design KV57 can include systematic rockbolt 4-5 m long, Spaced between 1 and $1.5 \mathrm{~m}$ in the crown and walls with a wiremesh $100-150 \mathrm{~mm}$ in the crown and inside $100 \mathrm{~mm}$ with light to medium ribs of $1.5 \mathrm{~m}$ as needed.

\section{Conclusions}

In conclusion, the characteristics of the rock mass and the environmental conditions of the area were collected to make a preliminary stability assessment of the Eighteenth Dynasty Tomb KV57. A digital 3D model was developed in PLAXIS 3D using the solidified soil modeling method, which indicates the importance of bulge pressure and vertical joints on the underground structure stability of KV57.

Detailed geo-environmental monitoring of remote sensing accompanied by detailed geotechnical analysis of the Tomb of Horemheb KV57 in Luxor, Egypt, showed that these unique underground structures provide low static safety factors for the structurally damaged roof and rock columns under the current conditions of geostatic stress. Where the FS is about 0.9, (note that the acceptable safety factor for underground structures is $>1.6$ in the steady state). The overpressure condition of the surrounding rocks exceeds the elastic system (field boundaries), and all structural supports of the roof, side walls and rock pillars are subjected to high vertical pressure stresses due to the high stresses in the site and weak 
Table 11 Guidelines for excavation and support of $10 \mathrm{~m}$ span rock tunnels in accordance with the RMR System (After Bieiniawski 1989)

\begin{tabular}{|c|c|c|c|c|}
\hline Rock mass class & Excavation & $\begin{array}{l}\text { Rock bolts } \\
\text { ( } 20 \mathrm{~mm} \text { diameter, fully } \\
\text { grouted) }\end{array}$ & Shotcrete & Steel sets \\
\hline $\begin{array}{l}\text { I-Very good rock } \\
\text { RMR: } 81-100\end{array}$ & $\begin{array}{l}\text { Fullface, } \\
3 \text { m advance }\end{array}$ & \multicolumn{3}{|c|}{ Generally no support required except spot bolting } \\
\hline $\begin{array}{l}\text { II-Goodrock } \\
\text { RMR:61-80 }\end{array}$ & $\begin{array}{l}\text { Fullface, } \\
1-1.5 \text { m advance. Complete } \\
\text { Support } 20 \text { m fromface }\end{array}$ & $\begin{array}{l}\text { Locally, bolts in crown } \\
3 \text { m long, spaced } 2.5 \text { m } \\
\text { with occasional wire mesh }\end{array}$ & $\begin{array}{l}50 \mathrm{~mm} \text { in crown } \\
\text { Where required }\end{array}$ & None \\
\hline $\begin{array}{l}\text { III_Fair rock } \\
\text { RMR:41-60 }\end{array}$ & $\begin{array}{l}\text { Top heading and bench } \\
1.5-3 \mathrm{~m} \text { advance in top heading } \\
\text { Commerce support after each blast } \\
\text { Complete support } 10 \mathrm{~m} \text { from face }\end{array}$ & $\begin{array}{l}\text { Systematic bolts } 4 \mathrm{~m} \text { long } \\
\text { Spaced } 1.5-2 \mathrm{~m} \text { in crown } \\
\text { And walls with wire mesh } \\
\text { In crown }\end{array}$ & $\begin{array}{l}50-100 \mathrm{~mm} \text { in } \\
\text { crown and } 30 \mathrm{~mm} \\
\text { in sides }\end{array}$ & None \\
\hline $\begin{array}{l}\text { IV-Poor rock } \\
\text { RMR: } 21-40\end{array}$ & $\begin{array}{l}\text { Top heading and bench } \\
1.0-1.5 \mathrm{~m} \text { advance in top heading } \\
\text { Install support concurrently with excavation, } 10 \mathrm{~m} \\
\text { from face }\end{array}$ & $\begin{array}{l}\text { Systematic bolts } 4-5 \mathrm{~m} \\
\text { long, spaced } 1-1.5 \mathrm{~m} \text { in } \\
\text { Crown and walls with wire } \\
\text { mesh }\end{array}$ & $\begin{array}{l}100-150 \mathrm{~mm} \text { in } \\
\text { Crown and100mm } \\
\text { insides }\end{array}$ & $\begin{array}{l}\text { Light to medium ribs } \\
\text { Spaced } 1.5 \mathrm{~m} \text { where } \\
\text { required }\end{array}$ \\
\hline $\begin{array}{l}\text { V-Very poor rock } \\
\text { RMR: }<20\end{array}$ & $\begin{array}{l}\text { Multiple drifts } \\
0.5-1.5 \mathrm{~m} \text { advance in top heading } \\
\text { Install support concurrently with excavation. Shotcrete } \\
\text { as soon as Possible after blasting }\end{array}$ & $\begin{array}{l}\text { Systematic bolts } 5-6 \mathrm{~m} \\
\text { Long spaced } 1-1.5 \mathrm{~m} \text { in } \\
\text { Crown and walls with wire } \\
\text { mesh. Bolt invert }\end{array}$ & $\begin{array}{l}150-200 \mathrm{~mm} \text { in } \\
\text { crown, } 150 \mathrm{~mm} \text { in } \\
\text { sides,and50mm } \\
\text { On face }\end{array}$ & $\begin{array}{l}\text { Medium to heavy ribs } \\
\text { spaced } 0.75 \mathrm{~m} \text { with } \\
\text { steel } \\
\text { Lagging and forepol- } \\
\text { ing if } \\
\text { required. Closed invert }\end{array}$ \\
\hline
\end{tabular}

geotechnical properties of marl limestone and oil shale. Several instability issues for static and dynamic loading were recorded and analyzed. As a result, a well-focused reinforcement and modification program is essential and urgently required since KV57 is closed due to instability and unsafe conditions.

\section{Abbreviations}

$A_{t}$ : Is the area supported by the pillar; $A_{p}$ : Is the area of the pillar; $\sigma_{v}$ : Is the vertical stress at the level of the roof of the excavation (KV5); $\sigma_{p}$ : Is the strength of the pillar, $\mathrm{W}$ and $\mathrm{H}$ : Are the width and height of the pillar respectively; qu: Is the UCS strength of the pillar material on cylinders with height (h) equal to twice the diameter; hcrit: Is the minimum height of the cubical specimen of pillar material such that an increase in the specimen dimension will produce no further reduction in strength.; $\beta$ : Angle between the normal to the fracture plane and the horizontal plane; $\varphi$ : Friction angle of the fracture; $x_{T}$ : Shear stress in resin annulus; $\sigma_{b}$ : Applied stress; $a$ : Decay coefficient $1 /$ in which depends on the stiffness of the system; $\beta$ : Reduction coefficient of dilation angle; $\sigma_{c}$ : Uniaxial compressive strength of rock; $A_{i}$ : Joint area; $\varphi_{b}$ : Basic joint friction angle; $D_{s}$ : Rib spacing; $U$ : The shear displacement at each step of loading; $\mathrm{C}$ Cohesion between block joints; $\sigma_{n}$ : Normal force; $b_{\mathrm{u}}$ : Shear displacement; $N_{\mathrm{p}}$ : Normal force at failure; $Q_{p}$ : Shear force at failure; $M_{D}$ : Bending moment at yield limit; $M_{p}$ : Bending moment at plastic limit; $E_{i}$ : Modulus of elasticity of intact rock; $Q_{c f}$ : Shear force; $L_{c p}$ : Reaction length; $v$ : Poison ration of rock mass; $P_{0}$ : In situ stress; JRC: Joint roughness coefficient; JCS: Joint compressive strength; RMR: Rock mass rating; RQD: Rock mass Designation; Q: Rock mass quality; Jn: Joint set number; Jr: Joint roughness number; Ja: Joint alteration number; Jw: Joint water reduction factor; SRF: Stress reduction factor.

\section{Acknowledgements}

Not applicable.

\section{Authors' contributions}

The whole database construction and analysis are presented in the manuscript had been achieved by the author. The author read and approved the submitted manuscript.

\section{Funding}

The author confirms that he is not currently in receipt of any research funding relating to the research presented in this manuscript.

\section{Availability of data and materials}

Data sharing not applicable to this article as no datasets were generated or analyzed during the current study.

\section{Competing interests}

The author declare that he has no competing interests.

Received: 29 September 2020 Accepted: 18 January 2021

Published online: 08 February 2021

\section{References}

1. McGlade J, Pulwarty R, Abrahams J, et al. GAR: global assessment report on disaster risk reduction 2019. Geneva, Switzerland: United Nations Office for Disaster Risk Reduction; 2019.

2. https://whc.unesco.org/archive/2019/whc19-43com-7B-en.pdf

3. Sawires R, Peláez JA, Fat-Helbary RE, Ibrahim HA, García Hernández MT. An updated seismic source model for Egypt, earthquake engineeringfrom engineering seismology to optimal seismic design of engineering structures, Abbas Moustafa. London: IntechOpen; 2015

4. Babacan AE, Akın Ö. The investigation of soil-structure resonance of historical buildings using seismic refraction and ambient vibrations HVSR measurements: a case study from Trabzon in Turkey. Acta Geophys. 2018;66:1413-33.

5. Sharafeldin MS, Essa KS, Youssef MA, Karsli H, Diab ZE, Sayil N. Shallow geophysical techniques to investigate the groundwater table at the Great Pyramids of Giza Egypt. Geosci Instrum Method Data Syst. 2019;8:29-43.

6. Chávez-García FJ, Natarajan T, Cárdenas-Soto M, et al. Landslide characterization using active and passive seismic imaging techniques: a case study from Kerala India. Nat Hazards. 2020. https://doi.org/10.1007/s1106 9-020-04369-y.

7. Bukovansky M, Richard DP, Week KR. Influence of slope deformations on the tombs in the valley of the kings, Egypt. Proc Int Symp Eng Geol Env. 1997;3(1997):3077-80. 
8. Alcaíno-Olivares R, Zeigler M, Perras MA, Maissen J. Cliff stability at tomb KV42 in the Valley of the Kings, Egypt: a first approach to numerical modeling and site investigation. In: The 53rd US rock mechanics/ geomechanics symposium held in New York, NY, USA, 23-26 June 2019.

9. Bardají T, Martínez-Graña A, Sánchez-Moral S, Pethen H, GarcíaGonzález D, Cuezva S, Cañaveras JC, Jiménez-Higueras A. Geomorphology of Dra Abu el-Naga (Egypt): the basis of the funerary sacred landscape. J Afr Earth Sci. 2017;131:233-50.

10. Dragowski A, Kaczynski R, Wroblewski J. Engineering-geological problems related to the reconstruction of the Hatshepsut Temple in Deir El-Bahari. In: Proceedings of the international symposium on the engineering geology of ancient works, monuments and historical sites-preservation and protection, IAEG, Athens, 19-23 September, vol. 1. Balkema. p. 161-8.

11. Rutherford JB. Geotechnical causes of ancient tomb damage: valley of the kings Egypt. Amsterdam: AA Balkema; 1990.

12. Reeves N, Wilkinson R. Complete valley of the kings, the tombs and treasures of Egypt's greatest pharaohs. Holborn: Thames and Hudson Ltd; 1966.

13. Lazar J. Geologisch-geotechnische Untersuchungen im Thebanischen Gebirge Teil Nord, Luxor Agypten, Universitat Bern, unpublished M.Sc. Thesis. 1995. p.161

14. McLane J, Wüst RA, Porter B, Rutherford J. Flash-flood impacts and protection measures in the Valley of the Kings, Luxor Egypt. APT Bull. 2003;34:37-45.

15. Hamada M, Aydan O, Tano H. A report on environmental and Rock Mechanical Investigations for the Conservation Project in the Royal Tomb of Amenophis III. In Conservation of the Wall Paintings in the Royal Tomb of Amenophis III_First and Second Phases Report. 2004. p. 83-138.

16. Tawfik HA, Zahran EK, Abdel-Hameed AT, Maejima W. Mineralogy, petrography, and biostratigraphy of the Lower Eocene succession at Gebel El-Qurn, West Luxor Southern Egypt. Arab J Geosci. 2010;4(3-4):517-34.

17. Cuezva S, García-Guinea J, Fernandez-Cortes A, Benavente D, Ivars J, Galán JM, Sanchez-Moral S. Composition, uses, provenance and stability of rocks and ancient mortars in a Theban Tomb in Luxor (Egypt). Mater Struct. 2016;49(3):941-60.

18. Verdel T. Géotechnique et Monuments historiques: Méthodes de modélisation appliquées à des cas Égyptiens. Doctoral Thesis, Institute National Polytechnique de Lorraine; 1993.

19. Ziegler M, Colldeweih R, Wolter A, Loprieno-Gnirs A. Rock mass quality and preliminary analysis of the stability of ancient rock-cut Theban tombs at Sheikh 'Abd el-Qurna, Egypt. Bull Eng Geol Environ. 2019;78(8):6179-205.
20. Wüst R, McLane J. Rock deterioration in the royal tomb of Seti I, Valley of the Kings, Luxor Egypt. Eng Geol. 2000;58:163-90.

21. KV57 Theban mapping project. 1997. http://www.thebanmappingproject .com/ Accessed 13th to 15th Apr 2020

22. Elfadaly A, Attia W, Lasaponara R. Monitoring the environmental risks around medinet habu and ramesseum temple at West Luxor, Egypt, using remote sensing and GIS techniques. J Archaeol Method Theory. 2018;25:587-610

23. Dunn J. The Geography and geology of the Valley of the Kings on the West Bank at Thebes. London; 2014.

24. Aubry MP, Dupuis C, Berggren WA. The role of geoarchaeology in the preservation and management of the Theban Necropolis, West Bank, Egypt. PYGS Proc Yorks Geol Soc. 2016;61:134-47.

25. https://roclab.software.informer.com/1.0/

26. Manual PLAXIS. Finite element code for soil and rock analysis. Comput Geotech. 2002;32(5):326-39.

27. Hemeda S, Pitlakis K. Serapeum temple and the ancient annex daughter library in Alexandria, Egypt: Geotechnical-geophysical investigations and stability analysis under static and seismic conditions. Eng Geol. 2010;113:33-43.

28. Hemeda S. Engineering failure analysis and design of support system for ancient Egyptian monuments in Valley of the Kings, Luxor Egypt. Geoenviron Disasters. 2018;5:12

29. Hemeda S. Numerical analysis of geotechnical problems of historic masonry structures. Geotech Geol Eng. 2020. https://doi.org/10.1007/ s10706-020-01638-2.

30. Hemeda S. 3D finite element coupled analysis model for geotechnical and complex structural problems of historic masonry structures: conservation of Abu Serga church Cairo Egypt. Herit Sci. 2019;7:6.

31. Salamon MDG, Munro AH. A Study of the strength of coal pillars. J South Afr Inst Min Metall. 1967:68(2):55-67.

32. Bieniawski ZT. Engineering rock mass classifications. New York: Wiley; 1989.

33. Brown ET. Risk assessment and management in underground rock engineering - an overview. J Rock Mech Geotech Eng. 2012;4(3):193-204.

34. Hemeda S, Sonbol A. Sustainability problems of the Giza pyramids. Herit Sci. 2020;8:8.

\section{Publisher's Note}

Springer Nature remains neutral with regard to jurisdictional claims in published maps and institutional affiliations.

\section{Submit your manuscript to a SpringerOpen ${ }^{\circ}$ journal and benefit from:}

- Convenient online submission

- Rigorous peer review

- Open access: articles freely available online

- High visibility within the field

- Retaining the copyright to your article

Submit your next manuscript at springeropen.com 